\title{
ROCK BORING BIVALVES AND ASSOCIATED FAUNA AND FLORA OF THE INTERTIDAL TERRACE \\ AT SANTA CRUZ, CALIFORNIA
}

$$
\text { Gerald Wayne Clark }
$$





\section{NAVAL POSTGRADUATE SCHOOL Monterey, California}

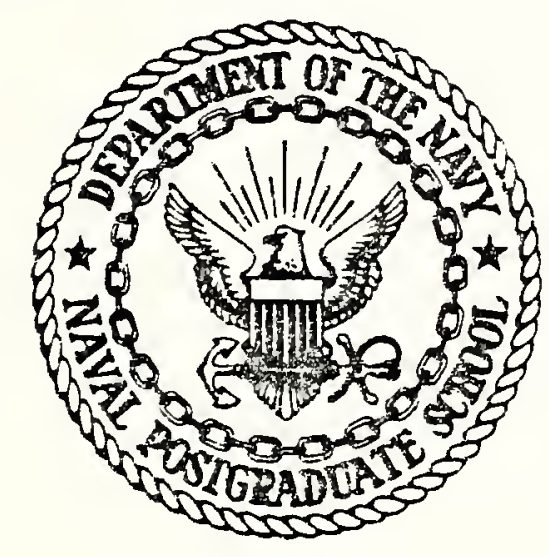

\section{THESIS}

\section{ROCK 3ORING BIVALVES ANE ASSOCIATED \\ FAUNA AND FLORA OE THE INTERTIDAL \\ IERRACE AT SANTA CRUZ, CALIEORNIA}

$$
\begin{gathered}
\text { by } \\
\text { Genald Wayne Clank } \\
\text { September } 1978
\end{gathered}
$$

Thesis Advison:

E. C. Haderlie

Approved for public release; distribution unlimited. 



\begin{tabular}{|c|c|}
\hline REPORT DOCUMENTATION PAGE & $\begin{array}{c}\text { READ INSTRUCTIONS } \\
\text { BEFORE COMPLETING FORM } \\
\end{array}$ \\
\hline \multirow{2}{*}{$\begin{array}{l}\text { 4. TITLE (and subere) } \\
\text { Rock Boring Bivalves and Associated } \\
\text { Fauna and Flora of the Intertidal } \\
\text { Terrace at Santa Cruz, California }\end{array}$} & $\begin{array}{l}\text { 5. TYPE OF REPOAT PERIOO COVERED } \\
\text { Master'S Thesis; } \\
\text { September } 1978\end{array}$ \\
\hline & 6. PEAFORMING ORG. REPOAT NUMEER \\
\hline $\begin{array}{l}\text { 7. Autroa(口) } \\
\text { Gerrald Wayne Clark }\end{array}$ & 6. CONTAACT OR GRANT NLMOER(:) \\
\hline 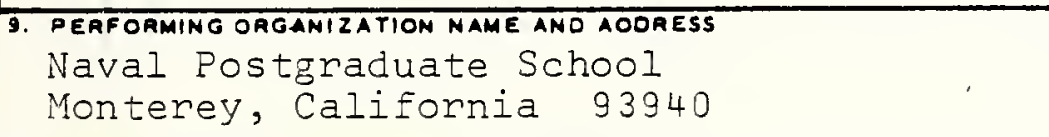 & $\begin{array}{l}\text { 10. PROGAAM ELEMENT, PROJECT, TASK } \\
\text { AREA W WOR UNIT NUMBERS }\end{array}$ \\
\hline \multirow{2}{*}{$\begin{array}{l}\text { 11. Contaolling office name ano aooress } \\
\text { Naval Postgraduate School } \\
\text { Monterey, California } 93940\end{array}$} & $\begin{array}{l}\text { 12. AEPOAT DATE } \\
\text { September } 1978\end{array}$ \\
\hline & $\begin{array}{l}\text { 13. NUMEER OF PAGES } \\
80\end{array}$ \\
\hline \multirow[t]{2}{*}{ 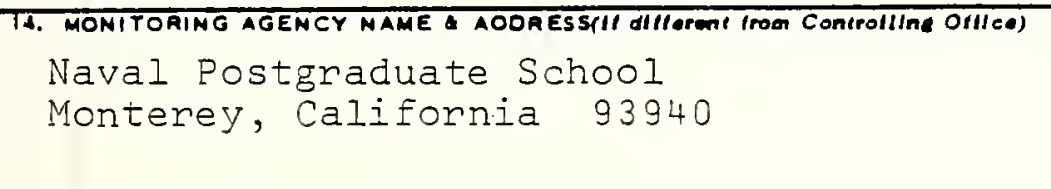 } & $\begin{array}{l}\text { 15. SECUAITY CLASS. (of this raport) } \\
\text { UnClassified }\end{array}$ \\
\hline & $\begin{array}{l}\text { 15. DECLASSIFICATIONIDOWNGAAOING } \\
\text { SCHEDULE }\end{array}$ \\
\hline
\end{tabular}

Approved for public release; distribution unlimited.

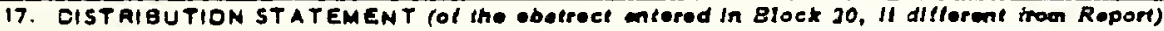

18. SUPPLEMEN TAAY NOTES

19. KEY wOROS (Continue an ferarce alde II naceceery and Identify by block number)

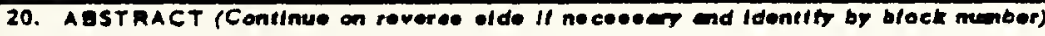

Two areas along the intertidal terrace at Santa Cruz, California, were surveyed for rock boring bivalves. At one location, all associated macroscopic epibenthic fauna and flora were identified and quantified. Rock samples were collected representing all rock types where borers were found. Results showed that Penitella penita was the most 

abundant rock borer in both locations, being found to heights of $2+$ meters above MLLW. The next most common borers were two species of Adula. Rock analysis showed that 32 out of 34 samples had calcium carbonate content less than $0.8 \%$ by weight, thereby indicating that in these locations the boring mechanism is probably not chemical. 

Approved for public release; distribution unlimited.

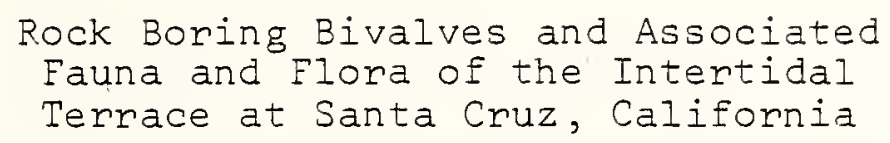

by

Gerald Wayne Clark

Lieutenant, United States Navy

B.S., Texas AEM University, 1969

Submitted in partial fulfillment of the

requirements for the degree of

MASTER OF SCIENCE IN OCEANOGRAPHY

from the

NAVAL POSTGRADUATE SCHOOL

September 1978 



\section{ABSTRACT}

Two areas along the intertidal terrace at Santa Cruz, California, were surveyed for rock boring bivalves. At one location, all associated macroscopic epibentric fauna and flora were identified and quantified. Rock samples were collected representing all rock types where borers were found. Results showed that Penitella penita was the most abundant rock borer in both locations, being found to heights of $2+$ meters above MLLW. The next most common borers were two species of Adula. Rock analysis showed that 32 out of 34 samples had calcium carbonate content less than $0.8 \%$ by weight, thereby indicating that in these locations the boring mechanism is probably not chemical. 

I. INTRODUCTION . . . . . . . . . . . . . . II A. OBJECTIVE OF STUDY . . . . . . . . . . . . . II

B. BRIEF RÉSUMÉ OF LITERATURE . . . . . . . . . 12

II. GENERAL GEOLOGY OF the MONTEREY BAy COASTLINE • . I3

III. AREAS OF STUDY . . . . . . . . . . . . . . . . 16

A. PRIMARY REEF AREA . . . . . . . . . . . . . I

1. General and Geological Characteristics . . I6

2. Wave and Tide Influence . . . . . . 23

B. TRANSECT AREA . . . . . . . . . . . 25

IV. METHODS .................. 28

A. SITE SELECTION . . . . . . . . . . 28

B. SITE DIVISION, MARKING, AND MAPPING .... 28

1. Primary Area . . . . . . . . . . 23

2. Transect Area . . . . . . . . . 30

C. VERTICAL ELEVATION DETERMINATION . . . . . 31

1. Primary Area . . . . . . . . . . 31

2. Transect Area . . . . . . . . . . 31

D. OBSERVATIONAL TECHNIqUeS . . . . . . . . 32

1. Gross Topography and Epibenthic

2. Borer and Nestler Identification. . . . . 33

3. Underwater Observations . . . . . . 35

E. CARBONATE ANALYSIS . . . . . . . . . 35

F. PETROGRAPHIC ANALYSIS OF ROCK SAMPLE . . . . 37 

V. OBSERVATIONS AND RESULTS . . . . . . . . . . . 39

A. PRIMARY REEF AREA . . . . . . . . . . . . . 39

B. TRANSECT AREA . . . . . . . . . . . 56

C. UNDERWATER SURVEY . . . . . . . . . . . . 61

D. CARbonate ANALYSis . . . . . . . . . . . 62

E. PETROGRAPHIC ANALYSIS . . . . . . . . . 62

F. GENERAL DISCUSSION . . . . . . . . . 64

VI. OBSERVATIONS AND IMPORTANCE OF BORERS

ON COASTAL EROSION . . . . . . . . . . . . 66

LITERATURE CITED • • . . . . . . . . • . . . . . 77

INITIAL DISTRIBUTION LIST . . . . . . . . . 79 



\section{LIST OF TABLES}

I. Average Height of Quadrats Above MLLW

(in Meters)............ . 20 20

II. List of Species... . . . . . . . . . . 40

III. Numbers of Penitella penita Found in Primary Study Area . . . . . . . . . . . 47

IV. List of Borers Other Than Penitella penita

Found in Primary Reef Area .... .... . . . 49

V. List of Nestlers Found in Primary

Reef Area . . . . . . . . . . . . . . 55

VI. List of Borers Found in Transect Area . . . . . . 58

VII. List of Nestlers Found in Transect

Study Area . . . . . . . . . . . . . . 60

VIII. Table of Inorganic Carbon, Carbonate and

Assumed Calcium Carbonate Content of

Various Rock Samples . . . . . . . . . . . 63 

1. Index map of California showing general

location of study areas. . . . . . . . . . . . 14

2. Location of study areas at Santa Cruz, California ................. . 17

3. Map of primary reef area divided into quadrats . . 18

4. Cross-sectional profiles through primary reef area................... I9

5. Map of primary reef area showing quadrat numbering system and sectional location . . . . . 22

6. a) Map of transect study area with measured heights above MLLW

b) Cross-sectional profile of transect study area (to same scale)... . . . . . . . . .

7. Numbers of Penitella penita (according to boring stage) found in primary reef area . . . . . 46

8. Numbers of borers other than Penitella penita found in the primary reef area. . . . . . . 48

9. Numbers of nestlers found in primary reef area . . 54

10. Numbers of borers found in transect study area . . 57

11. Numbers of nestlers found in transect study area . . . . . . . . . . . . . . . . . . . .

12. Photo of sandstone terrace (Section III) on right and Sections $I V$ and $V$ on left . . . . . .

13. Photo of primary reef looking from section III across Sections IV and $V$ towards mudstone cliff. Photo shows relatively level but irregular surface of Section $V$. . . . . . . . .

14. Photo of Section $V$ of primary reef area showing tidepools formed in chert. . . . . . .

15. Photo of chert in section $V$ of primary reef area showing convoluted and fractured nature 

16. Photo of Section $V$ of primary reef area showing region of severe wave attack and area of flat siltstone . . . . . . . . . . . .

17. Photo of Section $V$ of primany reef area showing area of severe erosion of chert, flat siltstone region, and tidepools in chert. . . 69

18. View of vertical face of primary reef area looking across eastern surge channel . . . . . 70

19. View of vertical face of primany reef area as seen across western surge channel . . . . . . 70

20. View of flat intertidal area chosen for transect study area.. . . . . . . . . . . . 71

21. View of transect study area showing tidepools at lower level

22. View of rock in high region of transect study area showing fractured nature. . . . . . . .

23. View of rock in low region of transect study area showing unfractured nature . . . . . .

24. View from top of cliff overlooking primary reef area showing method of quadrat marking on upper surface

25. View of primary area across eastern surge channel showing method of marking vertical faces . 73

26. Equipment used to determine elevations above Mean Lower Low Water (MLLW) . . . . . . . . . 74

27. Equipment used to search for rock borers . . . . 74

28. View of massive Phragmatopoma californica colonies along western surge channel of Section I. . . . . . . . . . . . . 75

29. Close-up of Phragmatopoma californica colony showing Pollicipes polymerus protruding through colony ..........

30. Photo showing dense cluster of Penitella penita (more than 10 individuals are visible). Cluster is of $5 \times 15 \mathrm{~cm}$ area in section II of primary reef area with $1 \mathrm{~cm}$ of surface rock removed

31. Photo from area of severe wave erosion showing evidence of pholad burrowing 

I wish to express my sincere appreciation and deep founded gratitude to Dr. E. C. Haderlie whose assistance, inspiration and patience was invaluable throughout this project. I am also deeply indebted to Dr. Isabella A. Abbott, Hopkins Marine Station, for her assistance in identifying various algae; to Dr. H. Gary Greene, U. S. Geological Survey, for his assistance with the geological portion of this study; to Florence Lee-Wong, U. S. Geological Survey, for her petrographic analysis of the chert sample; to Neil Barnes and Carol Hirozowa, also of Geological survey, for their instruction on how to conduct the calcium carbonate analysis; to my diving partner LT. Peter Kallin; and to Dr.W. C. Thompson, Naval Postgraduate School, for his assistance in helping initially unravel some aspects of the geology of the study area.

My deepest appreciation goes to my wife Nancy who provided moral support when most needed and assisted me in all phases of the research. 



\section{INTRODUCTION}

A. OBJECTIVE OF STUDY

Because of the unique oceanographic environment of the Monterey Bay area, there is an abundant and diverse marine fauna and flora. This, coupled with the several research institutions in the area, has provided numerous opportunities for biological research. As a background for the present study a proposed plan to construct a new breakiater at Monterey has provided impetus for a detailed ecological study to serve as a reference baseline for any resulting ecological changes. Also, at the Naval Postgraduate School, there is an ongoing research program investigating the life history and distribution of rock boring bivalves under the direction of Prof. E. C. Haderlie. To date this research has stressed the subtidal portion of the Monterey Bay south of the Monterey Submarine Canyon, the intertidal regions being devoid of borers because of the hard igneous rock found around the Monterey Peninsula (Haderlie, 1976 ; Haderlie, Mellor, Minter, and Booth, 1974).

The object of this study was to expand the subtidal investigation to include two areas in the intertidal zone in the northern Monterey Bay to determine the general distribution of stone-boring bivalves and the associated epibenthic fauna and flora of terraces of sedimentary stone. 

B. BRIEF RÉSUMÉ OF LITERATURE

A search of the literature revealed that except for the work cited above, little has been published on rock-boring bivalves in the Monterey area. Addicott (1966) discussed fossilized rock-boring bivalves found in the Pliocene Purisima Formation near Pt. Santa Cruz. He reported that in fossiliferous sandstone 5 meters above sea level, platyodon cancellatus was the main species present. This same sandstone layer contained articulated valves of Saxidomus giganteus, Tresus nuttallii and Protothaca staminea. Greene (1977) reported pholad holes from dredged rock samples in the Monterey Canyon. Three unpublished theses (Booth, 1972; Bunnett, 1972; and Minter, 1971) were devoted to subtidal boring bivalves off Del Monte Beach in Monterey. 



\section{GEOLOGY OF THE MONTEREY BAY COASTLINE}

A considerable literature exists on the geology of the Monterey Bay coastline. The most recent and detailed study of the area is that of Greene (1977) which describes in detail the geology of the Bay area, both marine and terrestrial.

To even the most casual observer there are striking differences in the geology of the coastline of the Bay. In the southern portion of the Bay around the Monterey Peninsula (Figure 1) the predominant geological formation is the Santa Lucia granodiorite, a Cretaceous rock of considerable hardness. In contact with this across the Tularcitos Fault which crosses the shoreline in the vicinity of Monterey is the Miocene Age Monterey Formation with its siliceous shale and siltstone. One of the identifying characteristics of this formation is the occurrence of numerous concretions which Bramlette (1946) stated were formed from surrounding siliceous material cemented by carbonate. Stretching from Monterey north to La Selva Beach, the coastline is composed of sandy beaches and dunes. Just inland of the sand dunes, the area is covered with alluvium, stream material, on bay and lagoon material.

In the northern Bay near Santa Cruz the entire coast consists of sea cliffs composed of Quaternary marine terrace deposits overlying somewhat older sedimentary rock. At 



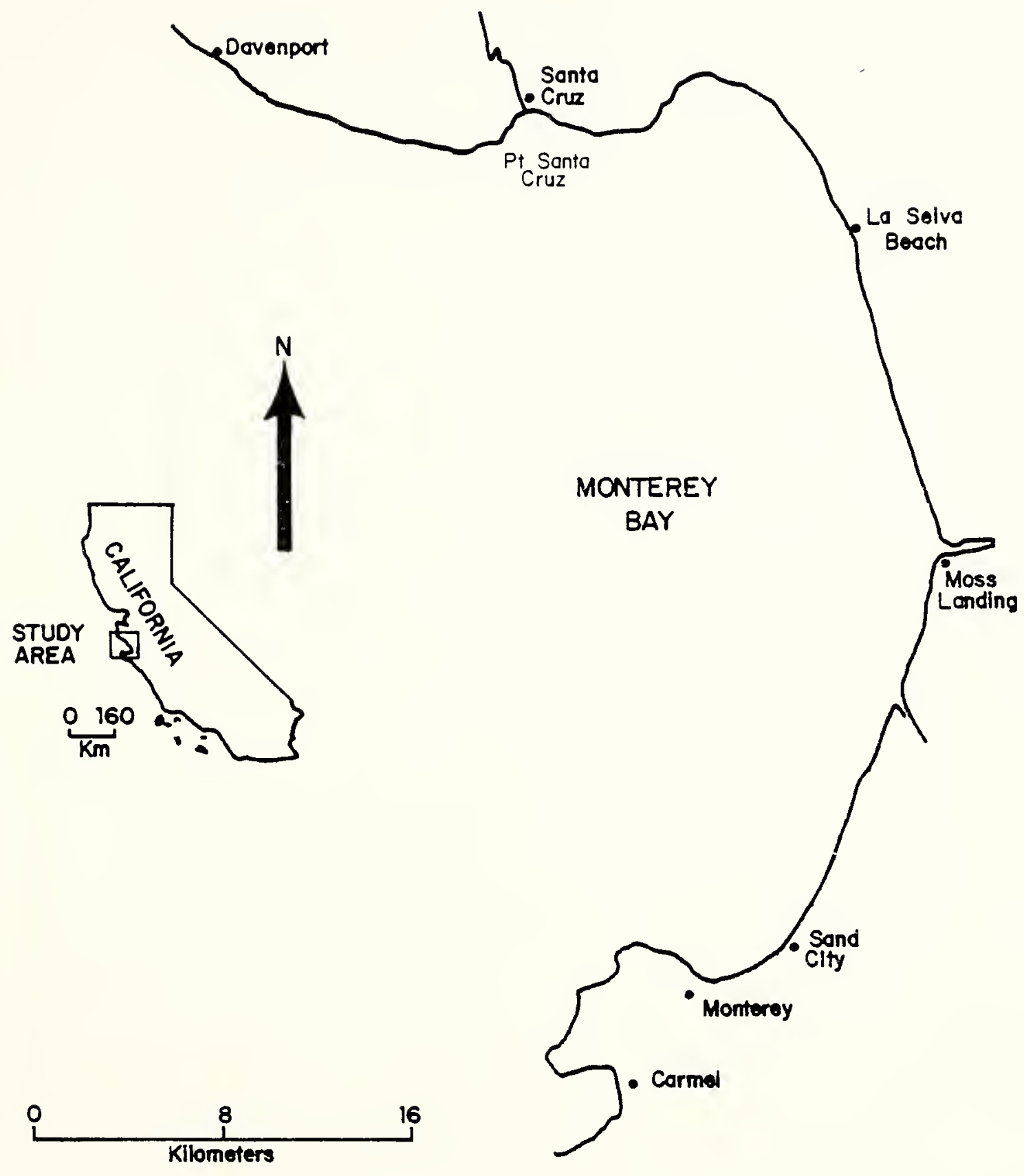

Figure 1. Index map of California showing general location of study areas. 

Point Santa Cruz the latter consists of Pliocene Purisima Formation with its yellow sandstone and siltstone, while west of Point Santa Cruz the sea cliffs and tidal zone rock terraces are composed of layers of chert of the Monterey Formation. The softer cliffs along the landward edge of the terraces are made up of the Pliocene Age Santa Cruz Mudstone of Clark (1966), a pale yellowish-brown siliceous organic mudstone of marine origin. Inland from these terraces are reported outcroppings of Santa Margarita Sandstone, Purisima Formation, metasedimentary rocks, granite, and older marine terraces.

In summary, the rocks of the intertidal zone in the southern part of Monterey Bay on the Monterey Peninsula are primarily of igneous origin and are extremely hard while those in the intertidal regions of the northern part of the Bay at Santa Cruz are of marine sediment origin and vary from hard to soft. 



\section{AREAS OF STUDY}

\section{A. PRIMARY REEF AREA}

1. General and Geological Characteristics

The primary intertidal reef chosen for detailed study is within the Santa Cruz City limits between Almar Street and Fair Street in the 1200 block of West Cliff Drive at the base of the concrete stairs $\left(36^{\circ} 56.09^{\prime} \mathrm{N} 122^{\circ} 02.51\right.$ ' W) used for public access (see Figures $I$ and 2). The reef itself is of triangular shape being $42 \mathrm{~m}$ long at its greatest extent and $25 \mathrm{~m}$ wide at its widest. It is bordered by and contiguous with the 5 meter high cliff discussed previously at the landward edge and surge channels on each side which open to the sea. The upper surface of the reef varies in elevation from $0.6 \mathrm{~m}$ above mean lower low water (MLLW) at the seaward edge to $3.1 \mathrm{~m}$ above MLLW at its highest point next to the cliff (Figure 3 and Table I). Figure 4 shows several cross sectional profiles through the reef. The contours on the reef generally parallel the coast as indicated by profiles A, B, and C. Profiles $D$ and $E$, which are perpendicular, show that the reef slopes up from the seaward point to a relatively high terrace then drops about 0.5 meter only to slope up again to the base of the cliff reaching its highest elevation there.

The reef is composed of several horizons of sedimentary rock which dip one on two degrees in the seaward 



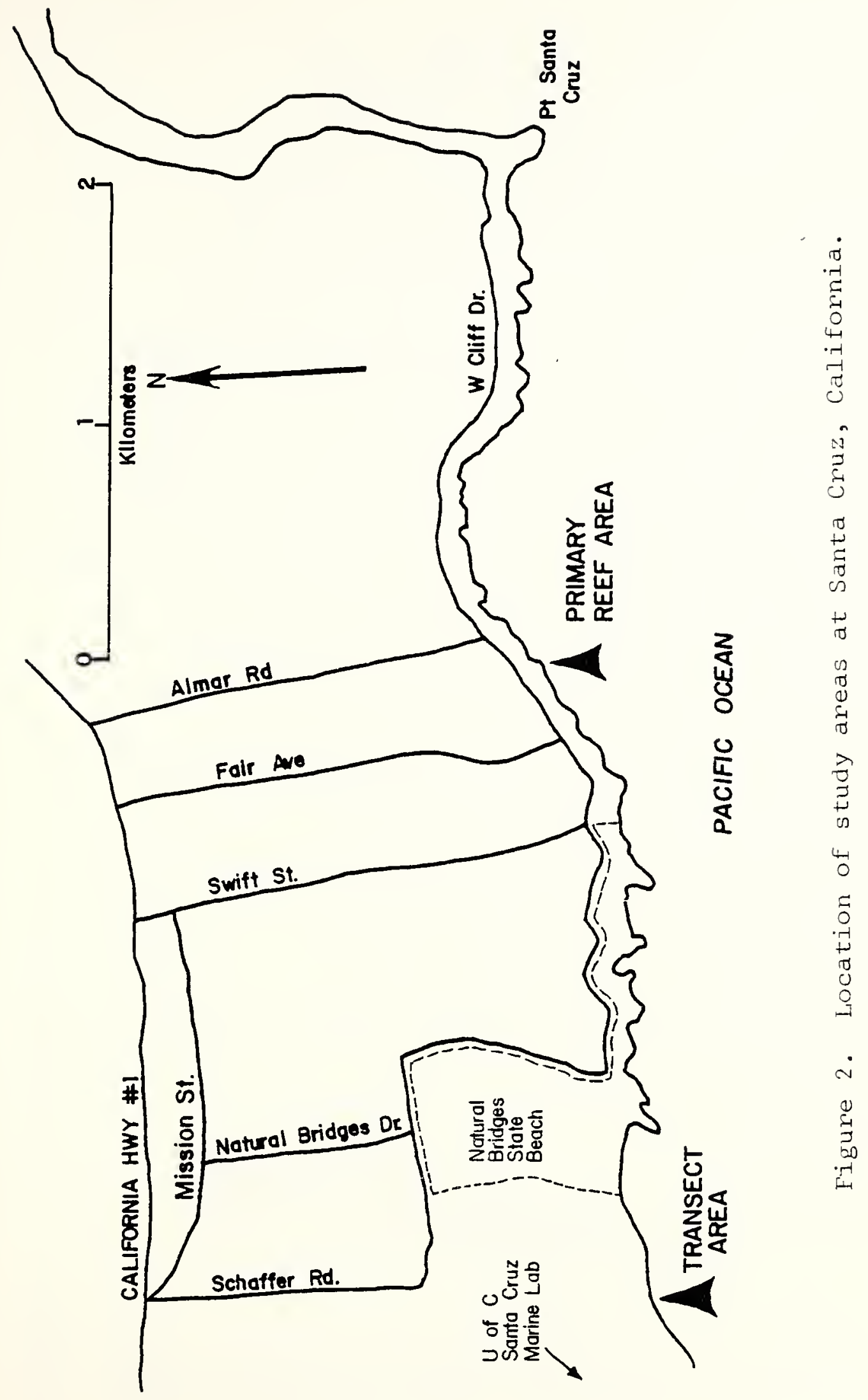





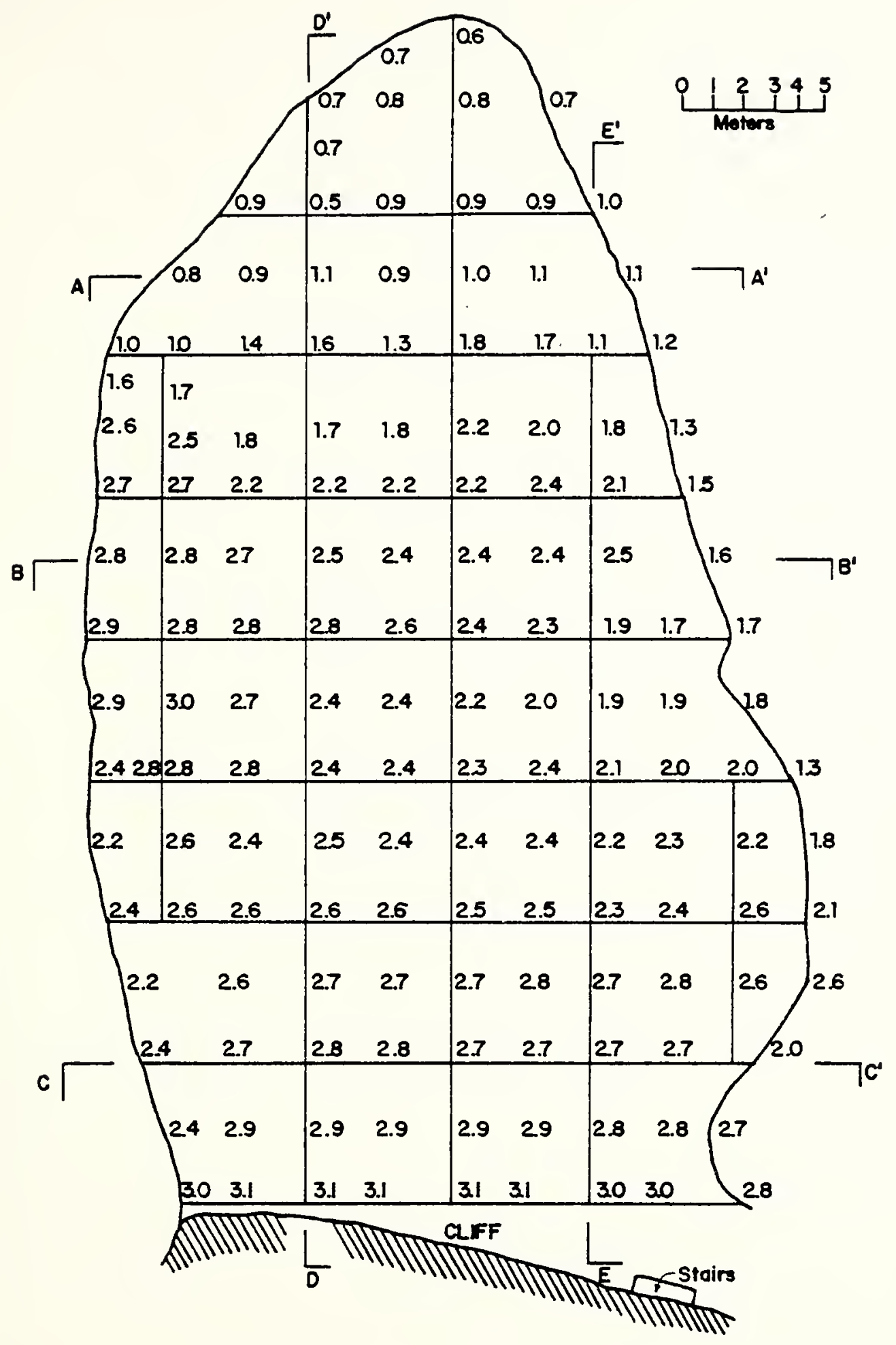

Figure 3. Map of primary reef area divided into quadrats. Elevations are in meters above MLLW. Cross-sectional profile locations are indicated by letters. 



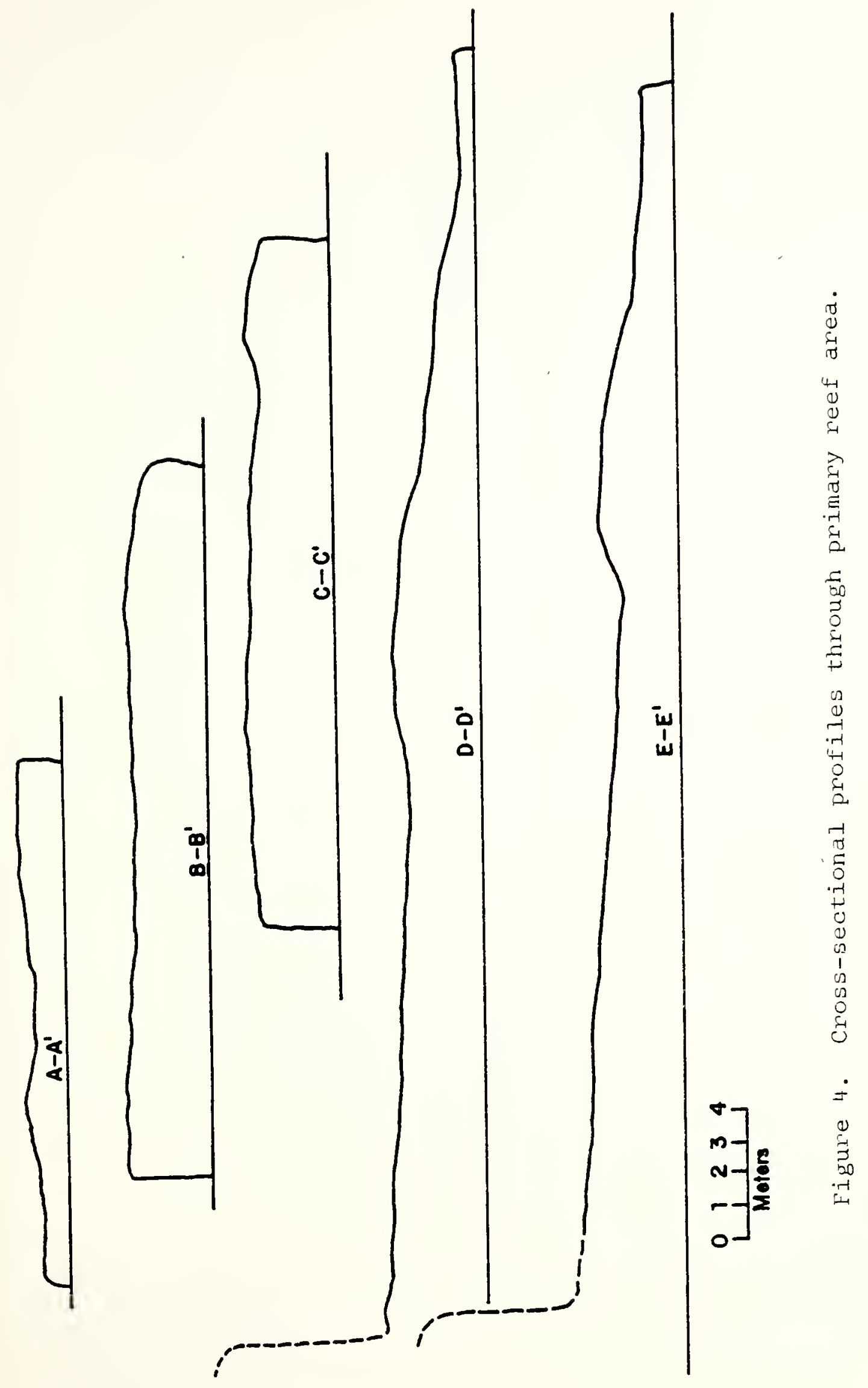



TABLE I

Average Height of Quadrats Above MLLW (in Meters) * Quadrat Average Height Quadrat Average Height

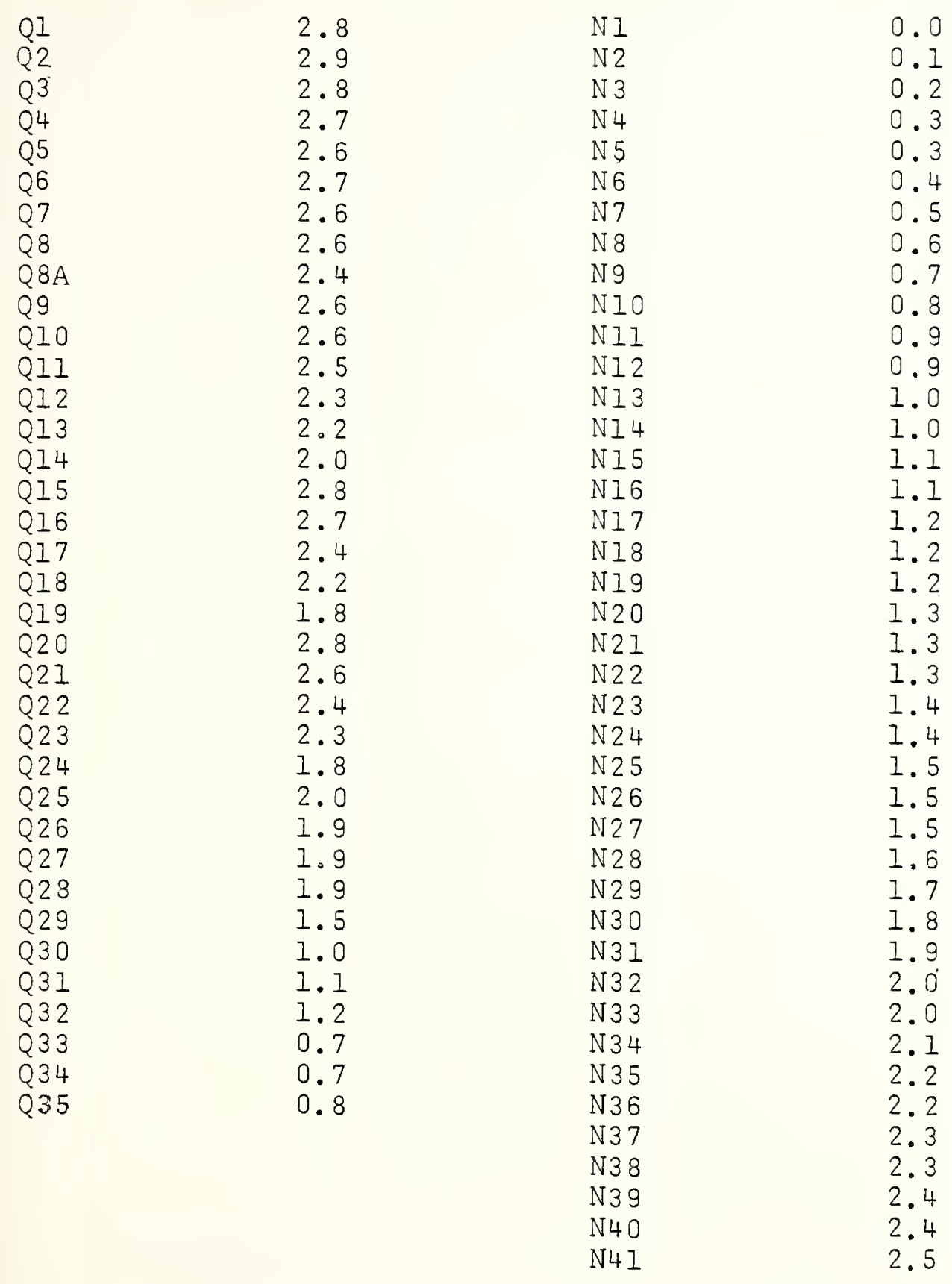

* Refer to Figures 5 and 6 for quadrat location. 

direction, but strike parallel to the cliff. The seawardmost area (Section I of Figure 5 ) is a layer of relatively hard chert (Green, 1978, personal communication) with numerous potholes and depressions which form tidepools up to $0.3 \mathrm{~m}$ deep and $0.5 \mathrm{~m}$ across. The bottoms of the tidepools are covered with a layer of sand and broken rock. Section II is a more abruptly sloping surface which slopes from 1.1 m above MLLW at the seaward portion to $2.0 \mathrm{~m}$ at the landwand portion. The rock grades from the hard chert at the lower level to a layer of siltstone, then a layer of chert, and finally a layer of somewhat softer, medium grained sandstone. Section III (Figure 12), the region of the high terrace with maximum elevation of $2.9 \mathrm{~m}$ above $M L L W$, is composed almost entirely of the medium grained sandstone with several shallow tidepools, the largest of which is $2 \mathrm{~m}$ across. The upper layer of this sandstone is high in iron content making it orange in color. Section IV is on the landward side of the terrace of section II and slopes from the upper surface of Section III down to about $2.1 \mathrm{~m}$ above MLLW. The geological composition varies from the medium grained sandstone sediment layer of the terrace to a hard chert layer at the lower landward portion of the section. There are no tidepools in this section. Section $V$ slopes upward from Section IV to the baseline of the study area near the edge of the cliff, reaching its highest elevation of $3.1 \mathrm{~m}$ above MLLW. This section is generally level, with numerous potholes and tidepools (Figure 13). The surface is generally a hard chert 



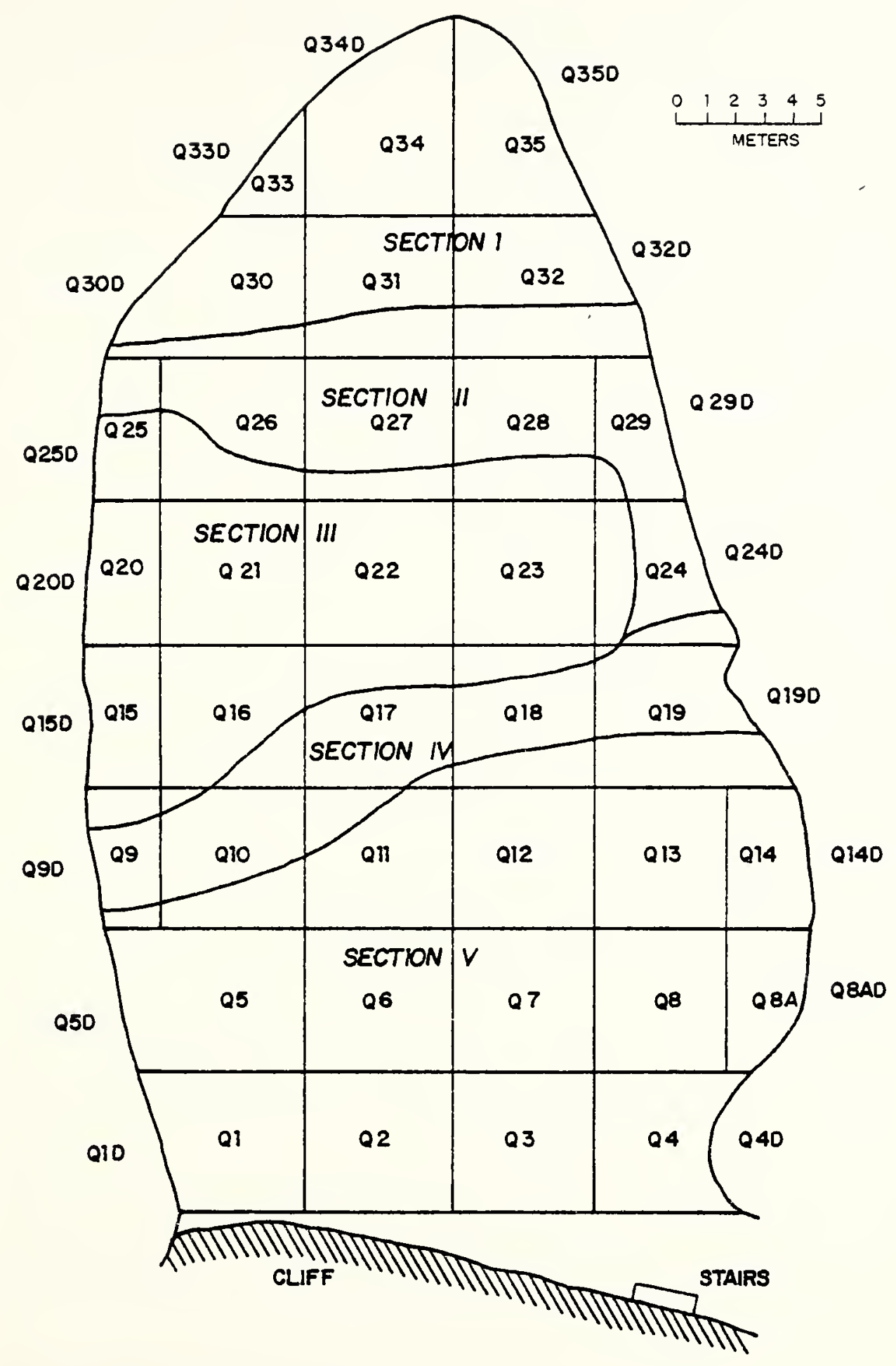

Figure 5. Map of primary reef area showing quadrat numbering system and sectional location. 

similar to that found elsewhere in the reef but is finely fractured (Figures 14 and 15). When doing any excavations with a hammer, the friable chert shatters with conchoidal breaks.

The vertical walls of the tidepools show a gradation from the friable fractured chert through a more solid chert to a softer fine grained siltstone at the base. Also, evident in this section are several rounded concretions (Figure 15) less than $0.25 \mathrm{~m}$ in diameter embedded in the chert plus one large doughnut shaped concretion about I.0 m across. The concretions are dolomitized in that they have been subjected to pressure and/or elevated temperatures and thus metamorphosed (Greene, personal communication).

Looking seaward, the seaward right flank of this section has been undercut by wave action which has eroded the upper portion of the softer layen of siltstone underlying the layer of chert. Thus the chert breaks off leaving this zone composed of the remaining flat siltstone (Figures 16 and 17).

2. Wave and Tide Influence

The seasonal wave regime on this part of the coast consists of storm waves and young swell in the winter season and typically long swell in the summer and early fall. The tidal datum planes relative to MLLW are as follows:

Mean higher high water (MHHW)

Mean high water (MHW)

Mean tide level (MTL)

Mean low water (MLW)

Mean lower low water
(MLLW)

$\frac{\text { Meters }}{1.6}$
1.4
0.9
0.3
0.0



The estimated highest water level is 2.4 meters above MLLW while the lowest water level is estimated at 0.8 meters below MLLW.

Exposure of the reef is highly variable depending on tide and wave conditions. With low tide and calm conditions all sections are exposed, while at high tide and calm conditions all of Section I and portions of Section II are submerged or at least wetted by wave action. With low swell $(<0.6 \mathrm{~m})$ Section $I$ is awash at low tide while Section I, pant of II, and part of $V$ are awash at high tide. With larger swell (> $1.3-1.6 \mathrm{~m}$ ) Section I and part of II are awash at low tide and sections I, II, III, parts of IV and $V$ are awash at high tide. Several times within the period of observation (February 1978 through July 1978) during stormy conditions waves were observed to completely submerge the entire reef up to the cliff base.

The vertical edges of the reef along the surge channels vary in height from less than $1 \mathrm{~m}$ to more than $3 \mathrm{~m}$. Because of the vertical nature of the walls with few horizontal ledges or edges, very few tidepools are present and those that are present are small, being less than $15 \mathrm{~cm}$ in diameter and less than $2 \mathrm{~cm}$ deep (Figures 18 and 19). These vertical faces clearly show 4 layers of sedimentary rock; the upper sandstone layer, exposed in Sections II, III, IV, the hard chert layer exposed in Section $V$, a hard siltstone layer exposed in Sections IV, V, and then the hard chert layer exposed in Section $I$. The surge channels them- 

selves at the beginning of the observations were relatively free of sand while by July sand had accumulated to a depth of about $1.5 \mathrm{~m}$ at the head end decreasing to about $0 \mathrm{~m}$ at the seaward end of the channel. This had the effect of burying under sand various portions of the vertical face.

\section{B. TRANSECT AREA}

In order to compare the primary reef studied with a much wider, gently sloping terrace, a second area was selected for study. This area is located approximately half way between Natural Bridges State Park and the University of California Marine Laboratory on Terrace Point.

The wide reef (Figure 20 ) of the transect area slopes gently down from the base of the cliff. The elevation of the area studied varies from MLLW at the seaward point to 2.5 meters above MLLW at the landward point 41 meters away (Table I and Figure 6). The surface of the reef is essentially a single layer of sedimentary chert with several tidepools at the lower levels (Figure 2I). These tidepools vary in size up to $1 \mathrm{~m}$ across and up to $0.75 \mathrm{~m}$ deep. The rock is somewhat fractured at the upper level (Figure 22) but relatively unfractured at the lower levels (Figure 23). No concretions or surge channels occur in this area of study. The exposure of the terrace is highly dependent on tide level and swell condition. The upper portion is wetted only with extreme tide and swell conditions as most of the wave energy is dissipated in turbulence at the lower levels on the long gradual run up. At low tide and with calm seas the only 



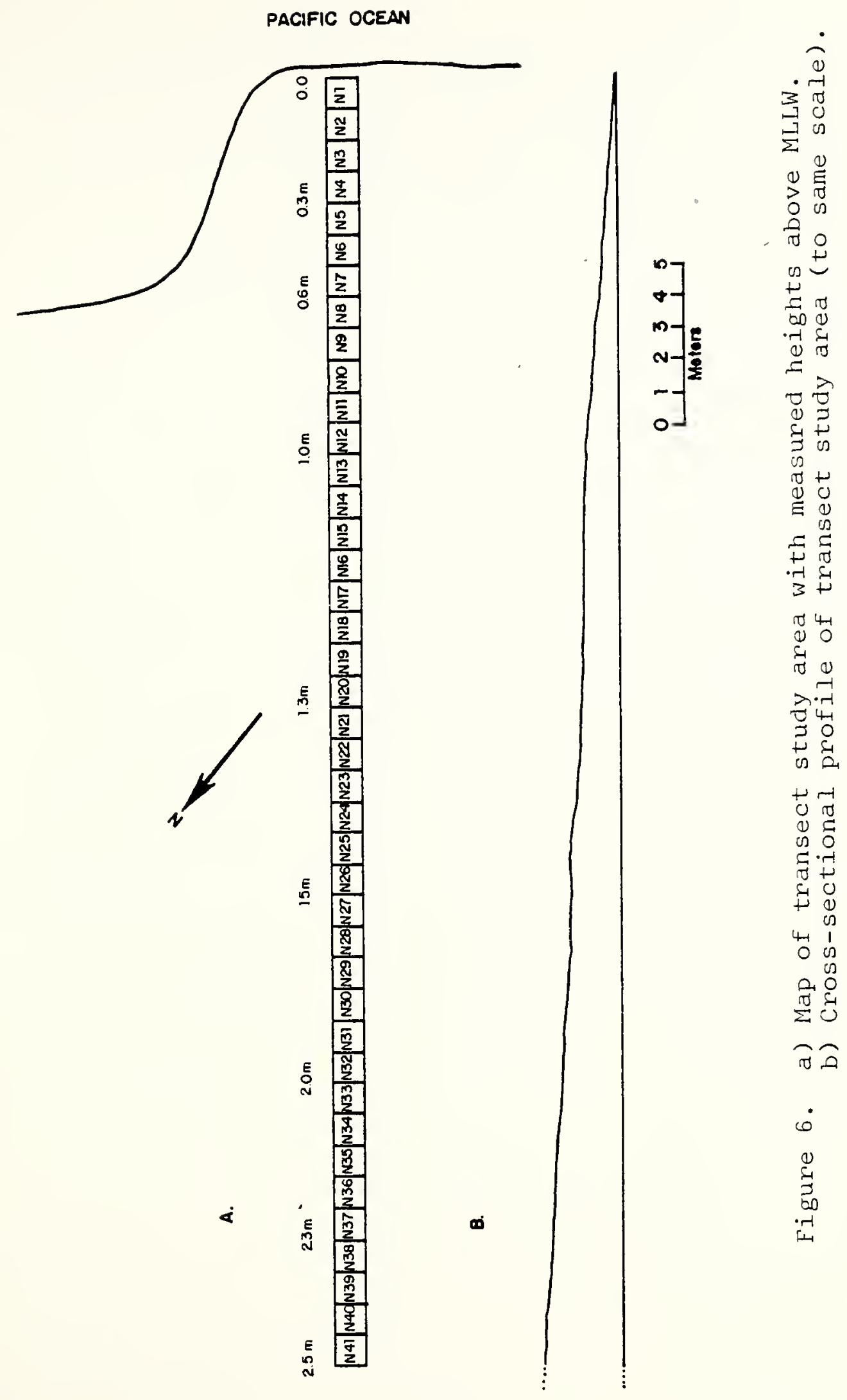



regions wetted are those in the tidepools. The first 25 meters or so of the sloping terrace above MLLW are usually wetted by normal high tide conditions. 



\section{METHODS}

\section{A. SITE SELECTION}

The sites were chosen to include two rather different but typical areas of the Santa Cruz coastline. The primary reef site was chosen because it was large and fairly typical of several along the shore. It also has the advantage of having concrete stairs nearby which facilitated the movement of survey equipment, buckets of specimens and other necessary items. The rock platform was also selected because it possesses a representative number of tidepools and enough. relief is available to expose several intertidal zones. Also, the area is large enough to allow a fairly diversified population to exist. The transect area was chosen because it is representative of the broad, gently sloping terrace characteristic of the shore west of Natural Bridges State Beach.

B. SITE DIVISION, MARKING, AND MAPPING

\section{Primary Area}

After the primary reef was selected it was decided to examine the reef systematically by dividing the site into sections of approximately 25 square meters $(5 \times 5 \mathrm{~m}$ squares or quadrats). This size quadrat was small enough to allow careful examination. To divide the reef into quadrats, two orthogonal reference lines were marked. One longitudinal line on a magnetic bearing of $297^{\circ}$ divided the reef length- 

ways, running from the seawardmost point of the reef to a point that bisected the landward portion of the reef (Figure 3). This range line was marked by driving into the rock a stainless steel marker at the seaward point, a stainless steel marker on the terrace in Section III of Figure 5 , and a lag bolt in the face of the cliff. To establish the landward edge of the study area, a base line perpendicular to the longitudinal line and roughly parallel to the cliff was constructed. This was permanently marked also by driving metal stakes into the rock at each end of the line.

Having completed these two reference lines, the reef was further divided by marking lines 5 and $10 \mathrm{~m}$ on either side of and parallel to the longitudinal reference line. These were permanently marked by driving metal stakes into the rock and cliff at each end of the line and on top of the terrace where 3 of the 4 lines pass over it. The remaining lines, those parallel to the base line, were marked in $5 \mathrm{~m}$ increments as needed.

Quadrat examination commenced at the baseline so that a line parallel to and 5 meters seaward of the baseline was marked and those quadrats along the baseline examined. Upon completion of examination of those quadrats, another line 5 meter seaward was marked and the next echelon of quadrats examined (Figure 24). After the entire upper surface was examined in this fashion, the areas along the vertical faces were examined. These were marked by suspending a weight on a line from the marking stakes at the edge of the upper surface (Figure 25). 

An examination of Figure 5 shows that all of the central quadrats are $5 \times 5 \mathrm{~m}$. Those quadrats along the edge of the reef vary in size because of the shape of the reef. As one looks seaward, the numbering system for the quadrats starts at the Iandward left flank and proceeds, left to right, thence seaward $I$ echelon and left to right again. This was repeated until the entire surface was covered. To differentiate the quadrats from those in the transect study area the numbers are prefixed by a Q. The vertical faces are numbered the same as the quadrat to which they adjoin on the upper surface and are suffixed by a D to distinguish them, for example QI and Q1D. The only deviation from this is Q8A which occurs between Q8 and Q9.

As each quadrat was examined, the outer boundaries were measured and a scale map was drawn on a sheet of graph paper. In addition, the major topographic features were noted on the map. This allowed the individual quadrate maps to be put together and one composite map to be drawn.

\section{Transect Area}

The site chosen was examined using the standard I $\mathrm{m}$ transect swath. One stake was driven into the rock substrate at MLLW and one stake in the rock at a point above the highest level of algae growth $41 \mathrm{~m}$ away, both on the transect. A line stretched between these stakes and marked off in $1 \mathrm{~m}$ increments served as the midline for a $1 \mathrm{~m}$ wide transect swath down the terrace (Figure 21).

The mapping of these squares was conducted at the same time that the general fauna and flora were examined. 

C. VERTICAL ELEVATION DETERMINATION

\section{Primary Area}

The primary area was surveyed using a Dietzgen 6000 series surveyors transit with standard Philadelphia rod (Figure 26) and converting the readings to metric measurements. A record from a previous study of the area conducted for other purposes in 1962 was obtained from City Hall in Santa Cruz. Using several of the points surveyed during that effort, an elevation reference point along the baseline was established. Then, using this reference, points approximately $2.5 \mathrm{~m}$ apart were surveyed over the entine reef. Figure 3 gives these values while Table I gives the average elevation of each quadrat located on the uppen sunface determined by averaging all elevation values located within the quadrat.

\section{Transect Area}

The elevations of this area were measured in the same way. Fewer readings were made because of the straight nature of the transect. Also, no absolute readings could be made due to the lack of any reference bench mark nearby. Thus, the lower stake was taken to be at MLLW as determined using tide tables, time of emplacement of the stake, and location of emplacement relative to water level. Figure 6 shows the elevation readings made along the transect plus a cross-sectional profile of the transect along the longitudinal axis of the transect. Table I gives the average height above MLLW determined by using a linear interpolation between the surveyed elevations. 

D. OBSERVATIONAL TECHNIQUES

1. Gross Topography and Epibenthic Species Identification

The preliminary work on each quadrat in the primary reef area consisted of describing the quadrat in terms of gross features, both geological and biological, plus making measurements for the subsequent map. This was followed by closer examination of the surface, crevices, and potholes in a back and forth sweeping motion across the quadrat to ensure all portions were examined. During this examination the identity of all macroscopic sessile species of animals and plants were recorded along with a notation of thein relative abundance. If a new or unknown species was encountered, a sample was taken and labelled for laboratory study. Once the observer gained familiarity with those species present, most organisms could be identified in the field. The greatest difficulty was with the red algae, which often requires microscopic examination before identification is possible. From the onset, a representative sample of every species properly identified was kept and preserved, thereby greatly facilitating identification of similar species found later. The effort in the transect area was slightly different in that the emphasis was mainly on the borers, hence only a cursory check of the epibenthic animals and plants was conducted. As the squares were only $I \times 1 \mathrm{~m}$, a few scans back and forth across the square was all that was required to identify and quantify the major onganisms present. As no species not found earlier on the primary reef were encountered, 

it was not necessary to collect samples for later identification. Notes pertaining to topography of each square were also made.

\section{Borer and Nestlen Identification}

Attempting to locate boring bivalves inside solid rock is certainly not easy. This is made more difficult because the examination of the quadrats was done when the water level was below the rocks being examined. This aerial state caused the bivalves to withdraw their siphons at least into the burrow. This meant that chipping away the rock was the only way to expose the specimens. For this purpose a geologist's rock pick was used at first. It was later found more convenient and more manageable to use a heavy duty 0.75 inch cold chisel and a 2 pound sledge hammer (Figure 27). This allowed more delicate work around the vicinity of specimens when trying to excavate a live specimen from its burrow.

While the only way to find, identify and quantify borens is to physically dig them out of rocks, it is also apparent that one cannot dig up over $1000 \mathrm{~m}^{2}$ of public recreational area. Thus it was necessary to use discretion. The basic premise was to use approximately the same amount of time and effort in the search in each quadrat. Each of the various types of rock and habitat (chert, sandstone, siltstone, tidepool, upper surface, crevice, etc.) were sampled in each quadrat. This allows one to draw conclusions as to the relative abundance of each species and its distribution relative to tidal zone. 

In the case of the Pholadidae, it is possible to differentiate between the active borers who are sexually immature and the sexually mature individuals who have ceased to bore. All of the actively boring pholads have an open pedal gape through which the foot extends. The shell, margins, along this anterior end, are ribbed presumably to aid in mechanical boring and have a hardness of $3.5-3.9$ on the Moh's scale (Evans, 1968a). The sexually mature adult specimens of Pholadidae, with the exception of Zirfaea pilsbryi and Barnea subtruncata, neither of which were found in this study, possess a callum which is a thin calcareous covering secreted over the pedal gape. Additionally, Penitella penita and Penitella conradi develop a siphonplax, in the formen case heavy flexible chitinous flaps and in the latter case heavy inflexible chitinous flaps lined with coarse calcareous granules.

\section{All specimens of live borers and nestlers which} were encountered were saved for later positive identification and preservation in the laboratory. This was required to separate the pholads Penitella penita and Penitella conradi in the boring state since identification required examination of the distal end of the extended siphons. Generally, whole specimens were obtainable but occasionally the rock surrounding the burrow would collapse during the excavation efforts and crush part or all of the specimen. Nevertheless, these were saved for microscopic examination which often allowed identification of even the most severely 

damaged. Concurrently with the collection of the boring bivalves, a sample of rock in which the borers were found was saved and later analyzed for carbonate content.

Identifications of all species of algae were made using Abbott and Hollenberg (1976); invertebrates in general were identified using the keys in Smith and Carlton (1975), while the boring bivalves were identified using Turner (1955). Dr. I. A. Abbott personally identified many questionable algae.

\section{Underwater Observations}

A cursory underwater survey consisting of four mandives in the primary reef area was completed using standard open circuit SCUBA equipment. The survey was conducted by swimming out on a straight line from the apex of the reef on approximately the same compass heading as the longitudinal line of the primary reef (i.e., $117^{\circ} \mathrm{M}$ ). While swimming out to a point where the water depth was $8 \mathrm{~m}$, observations were made on either side of the swimmers to the edge of visibility. This meant an area $5 \mathrm{~m}$ wide was covered with notes made on an underwater slate as to general topography, geology, and onganisms present. The two pound sledge hanmer and chisel were carried and used on various rock areas in the search for borers.

E. CARBONATE ANALYSIS

Carbonate analyses were made on selected rock samples in order to determine to what degree pholad-bored rocks were cemented by calcium carbonate. Those samples of rock saved 

for carbonate content determinations were analyzed using a Leco WI2 Carbon Determinator (ModeI 761-100) at the U. S. Geological Survey Annex in Menlo Park. The technique used was a basic method, i.e., subjecting the sample to HCI acid, measuring the $\mathrm{CO}_{2}$ gas given off and then calculating the $\mathrm{CO}_{3}$ of the sample based on the reaction:

$$
\mathrm{CaCO}_{3}+2 \mathrm{HCl} \rightarrow \mathrm{H}_{2} \mathrm{O}+\mathrm{CO}_{2}+\mathrm{CaCl}_{2}
$$

Assuming calcium carbonate is the only carbonate present, then the percent composition of $\mathrm{CaCO}_{3}$ can be calculated. Specifically, the sample of rock was either scraped or broken so that a piece from the center of the sample could be obtained. This was done to ensure that no contamination from organic carbonates occurred. The sample of rock was then crushed with a mortar and pestle until the sample could be passed through a Tyler screen with a mesh opening of $0.495 \mathrm{~mm}$. The sample was then dried by subjecting it to heat in a drying oven. From each rock, three samples were taken and analyzed, calculations completed, and then an average taken.

The treatment of each sample was the same, with approximately .050 to $.070 \mathrm{~g}$ of the sample being used. ApproximateIy $10 \mathrm{ml}$ of $10 \% \mathrm{HCl}$ was added to the sample which was then heated by an alcohol lamp to help drive the reaction to completion. The gas was passed through a sulfuric acid solution and several other reagents to absorb the $\mathrm{H}_{2} \mathrm{O}$, halides, hydrocarbons, and other elements leaving only the 

$\mathrm{CO}_{2}$ gas from the reaction. This gas was then passed through the carbon determinator.

The Leco WR-12 carbon determinator uses a thermalconductivity cell which has the ability to detect the difference in the thermalconductivity of gases. The cell consists, of a pair of matched thermistors used in two legs of a Wheatstone bridge. The "reference" thermistor is maintained in a constant gas $\left(\mathrm{O}_{2}\right)$, pressure, flow, and temperature environment while the "measure" thermistor is maintained in a constant pressure, flow, and temperature environment, but the gas composition is allowed to vary. Once the bridge is balanced, varying the gas allows the thermistor temperature to change due to difference in thermalconductivity. This will cause an output to be available in the preamp of the electronics system which gives a meter reading. The amount of $\mathrm{CO}_{2}$ in the "measure" gas determines the magnitude of reading, with the sensitivity of the systen governed by the difference in thermalconductivity between the $\mathrm{CO}_{2}$ and the $\mathrm{O}_{2}$ (themalconductivity for $O_{2}$ is $5.7 \times 10^{-5}$ calories $/ \mathrm{cm} \mathrm{sec}{ }^{\circ} \mathrm{C}$ and that for $\mathrm{CO}_{2}$ is $3.3 \times 10^{-5}$ calories/cm sec ${ }^{\circ} \mathrm{C}$ ). The advertised sensitivity of the system is $0.005 \%$ carbon with an accuracy of $\pm 0.0005 \%$ carbon which equals $0.0417 \%$ calcium carbonate with an accuracy of $\pm 0.00417 \%$.

\section{F. PETROGRAPHIC ANALYSIS OF ROCK SAMPLE}

In order to determine the mineral constituents of the chert, a sample from Section $V$ was obtained from the seaward right flank where wave attack is most severe. This rock 

sample was forwarded to Dr. Greene at the U. S. Geological Survey Annex in Menlo Park who had a thin section made. Florence Lee-Wong, a petrographer at the Geological Survey Annex, then conducted an examination of the thin section. 



\section{OBSERVATIONS AND RESULTS}

\section{A. PRIMARY REEF AREA}

One of the goals of this study was the identification and quantification of the epibenthic organisms on an intertidal reef. The data collected is presented in Table II which lists the 42 species of marine plants and the 40 species of invertebrates identified. The highly mobile animals, such as the lined shore crab, Pachygrapsus crassipes, are not listed nor are species of algae that were not attached to the substrate.

Table II shows that as one progresses out toward the apex of the reef, there is a smaller and smaller population of green algae (Chlorophyta). The brown algae (Phaeophyta) show the same trend with the exception of Laminaria sinclairii and Egregia menziesii which become the dominant two species in the wave swept lower terrace (Section I). The red algae (Rhodophyta), while having the largest number of species present, has a smaller biomass than the browns. Likewise, there is a trend toward smaller biomass as one approaches the apex of the reef. The two notable exceptions to this are: (a) the epiphytic Smithora naiadum growing on the surfgrass, Phyllospadix scouleri, which becomes abundant in the lower reaches of the intertidal reef, and (b) Prionitis lanceolata. 


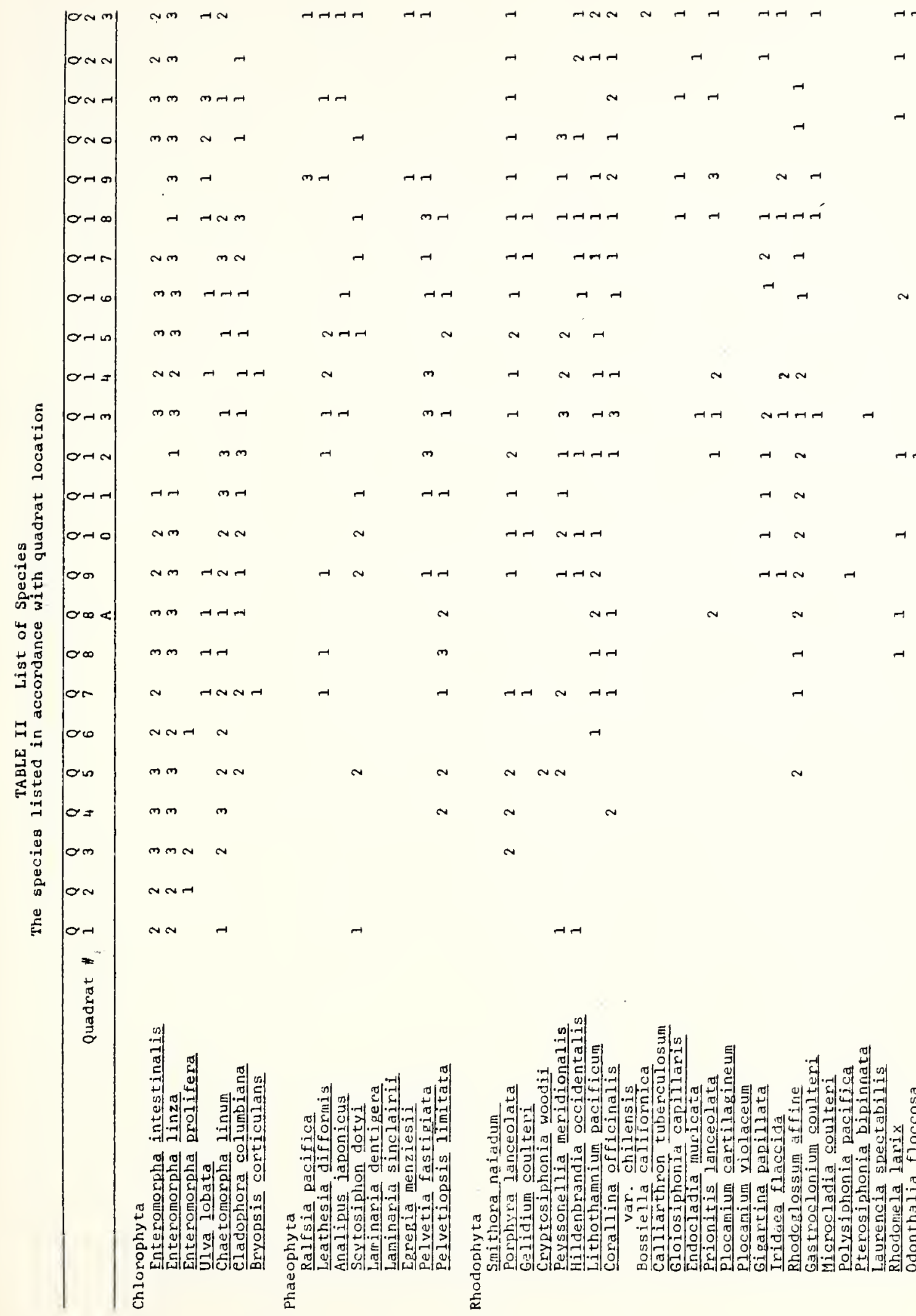

n n n
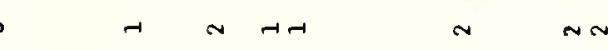

$-1-1$

$m$

N $4 \pi-1$

$-4$

$-N$

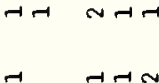

$\rightarrow \rightarrow n$

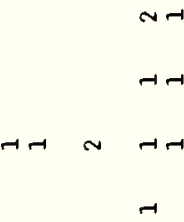

v

$N$ 



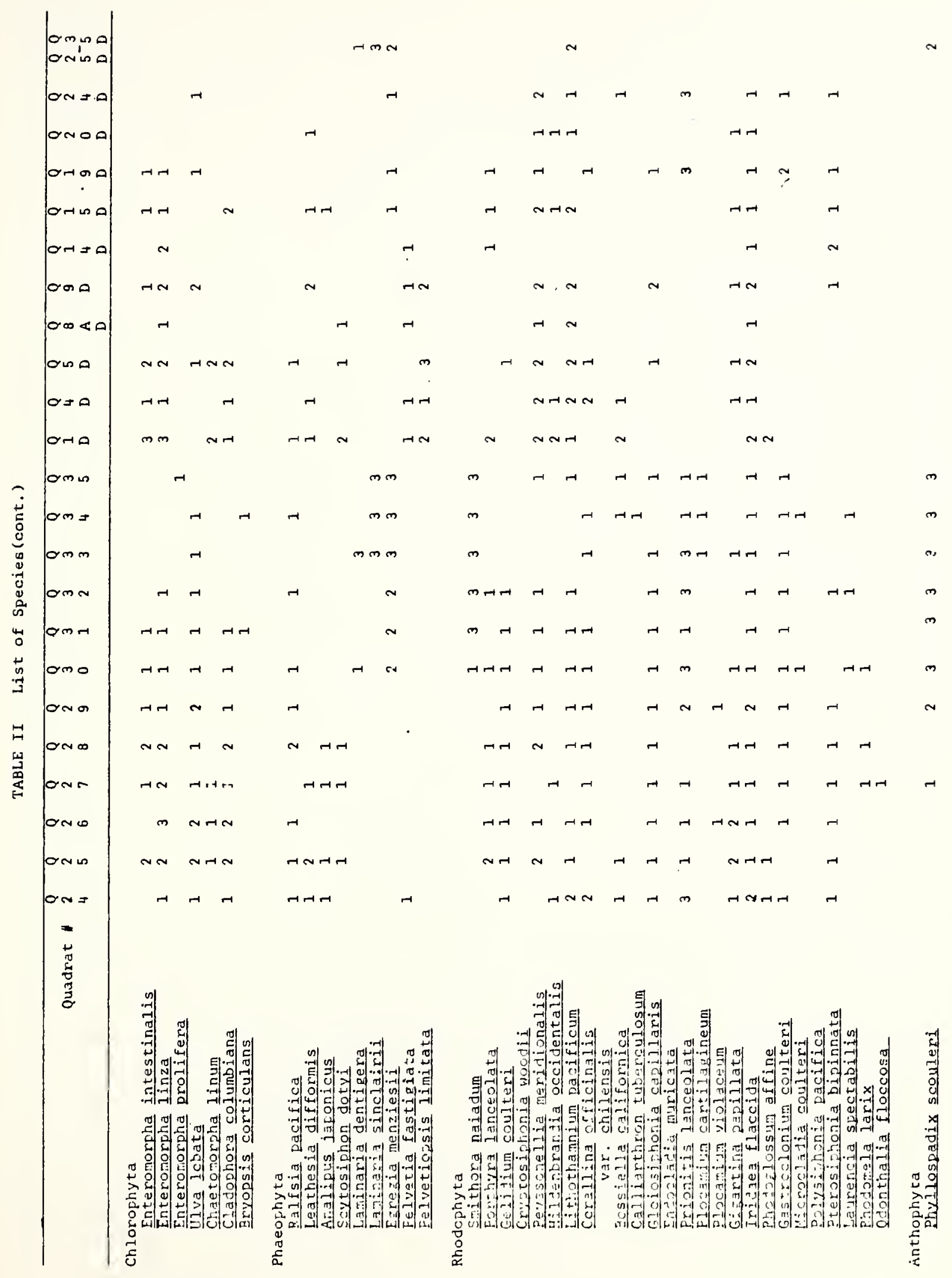





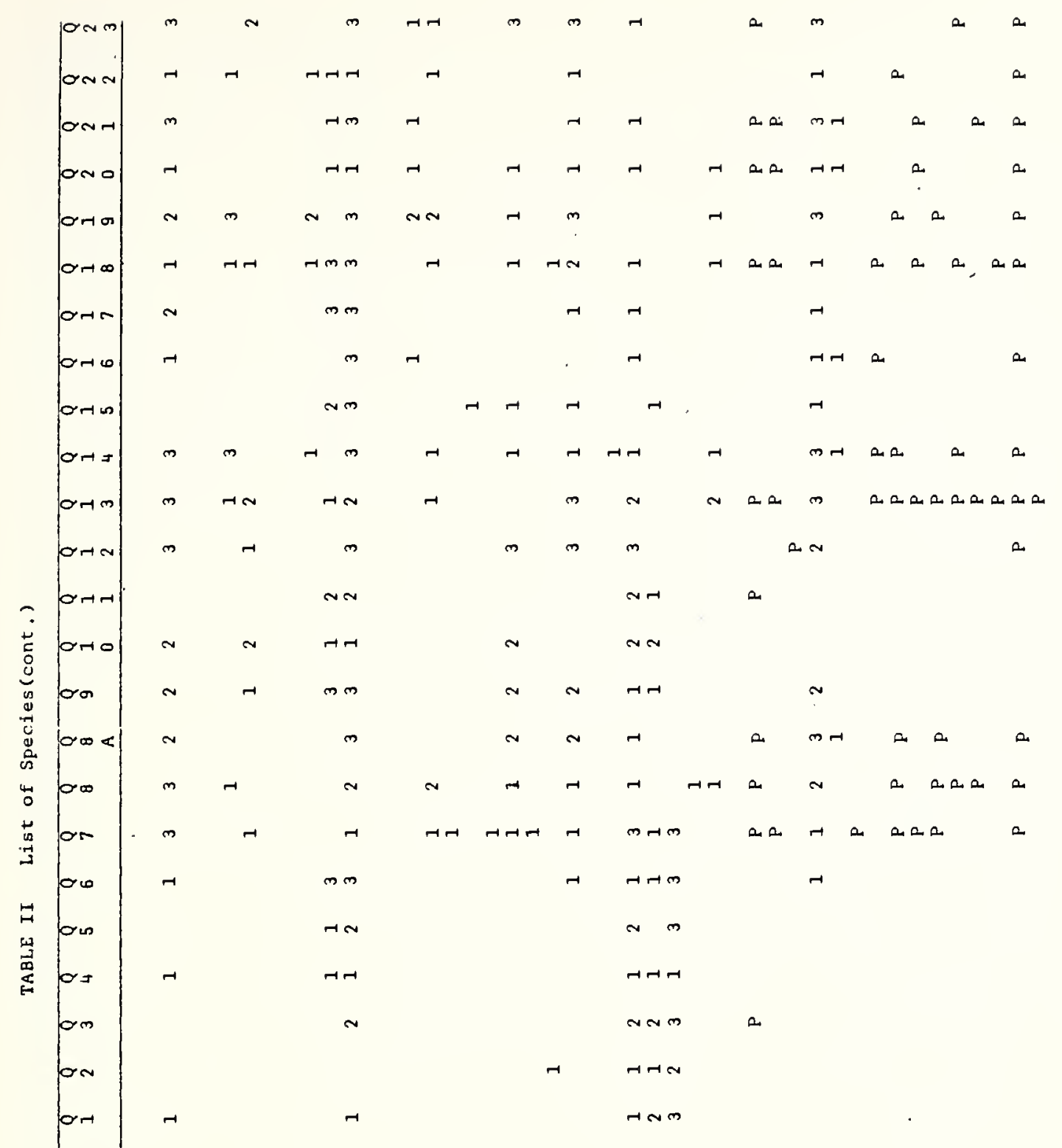

녈 


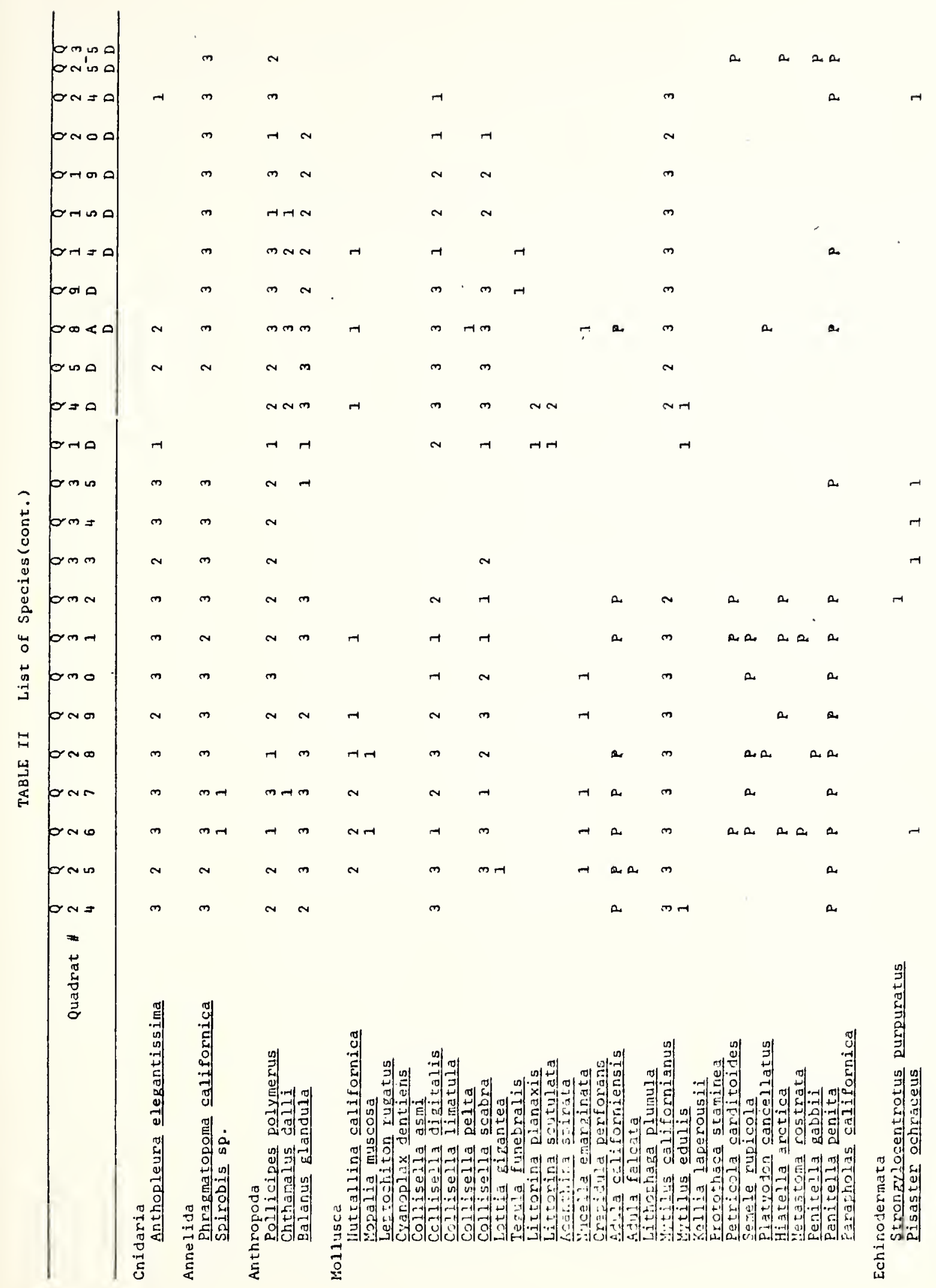

TABLE II. List of Species (cont.)

Symbols used in table:

I Rare found only singularly or occasionally in quadrat

2 Common found frequently in quadrat

3 Abundant found in large numbers in quadrat

$P$ Present in quadrat, quantity given in other tables 

In the case of animals, as the apex is approached the numbers of Tegula funebralis, Littorina planaxis, and Littorina scutulata decrease indicative of the fact that these species are high intertidal dwellers. Conversely, Anthopleura elegantissima, Mytilus californianus, and Pollicipes polymerus become more numerous. Of particular interest was the increasing abundance of Phragmatopoma californica colonies as the seaward portion of the reef is approached. Massive tube worm clusters were encountered along the vertical faces as well as along the upper surface of the lower part of the reef. Some of the colonies of worms reached dimensions of several meters long and more than $0.3 \mathrm{~m}$ thick. Figure 28 shows the massive numbers and size of these colonies along the western flank of section I. Figure 29 , a close-up, shows Pollicipes polymerus growing through the tube worm colony.

Figures 7 and 8 and Tables III and IV list the numbers of the various boring bivalves found in the quadrats. Penitella penita is by far the most common borer in this intertidal area which agrees with observations made by Evans (1968c) for the Oregon intertidal zone and by Tuner (1955) for the eastern Pacific Ocean in general. $\underline{\text { P. penita }}$ were found in virtually every type of rock on the reef with the exception of the fractured, friable chert in the higher intertidal area. This could be due to the hardness of the rock which might prevent boring or to the dryness during the low tide conditions killing the young larvae. Table III 



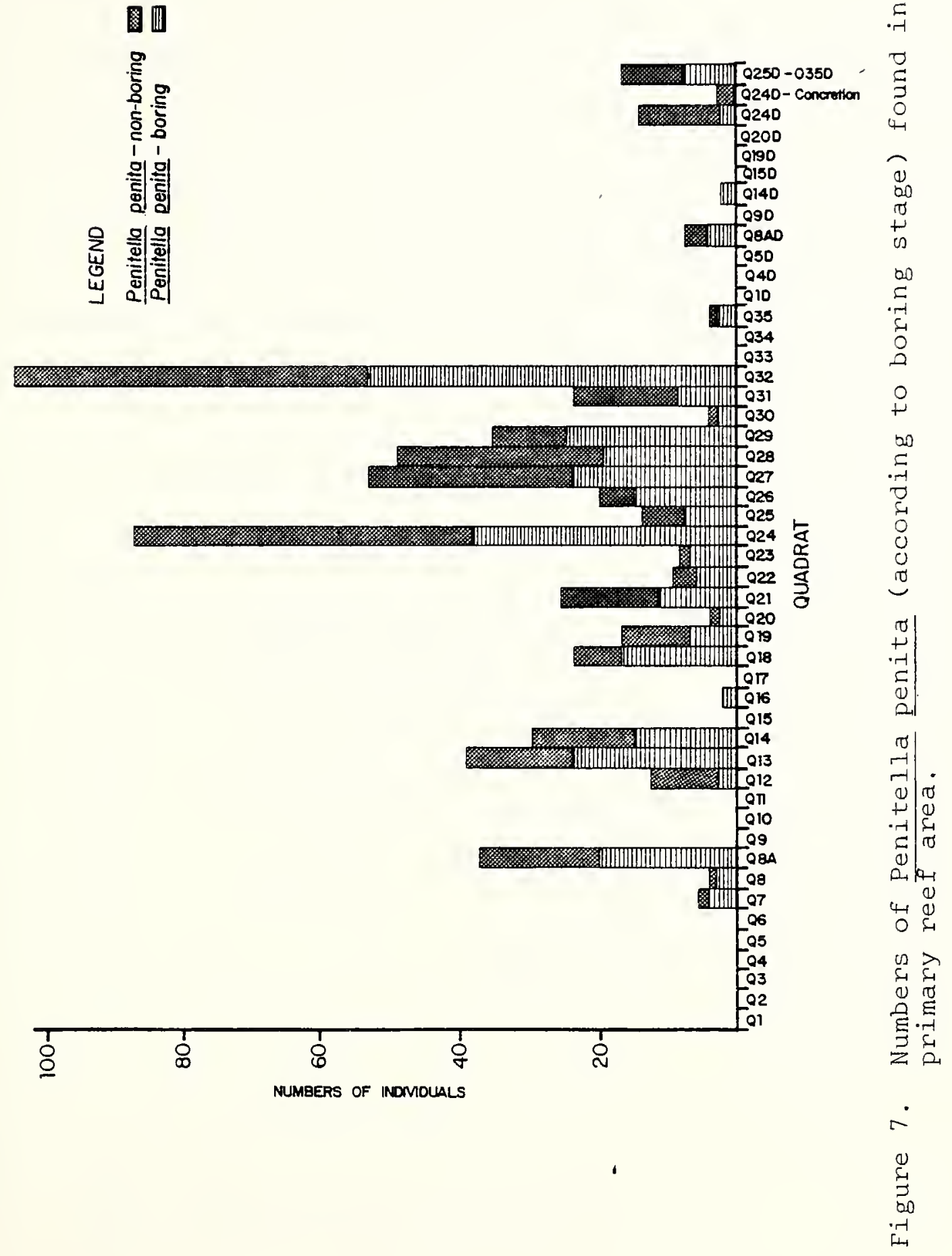





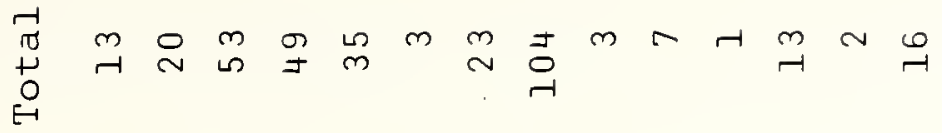

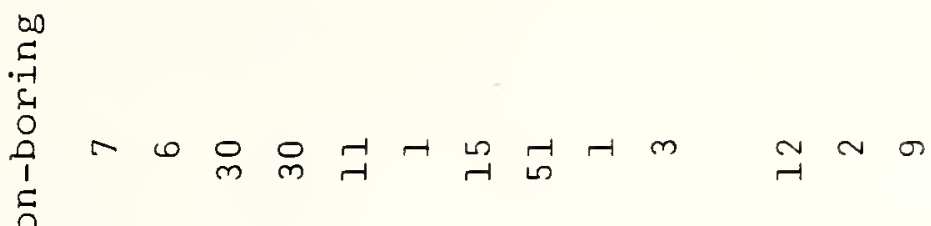

$$
\begin{aligned}
& \begin{array}{ll}
0 & 1 \\
0 & 0 \\
2 & 2
\end{array}
\end{aligned}
$$

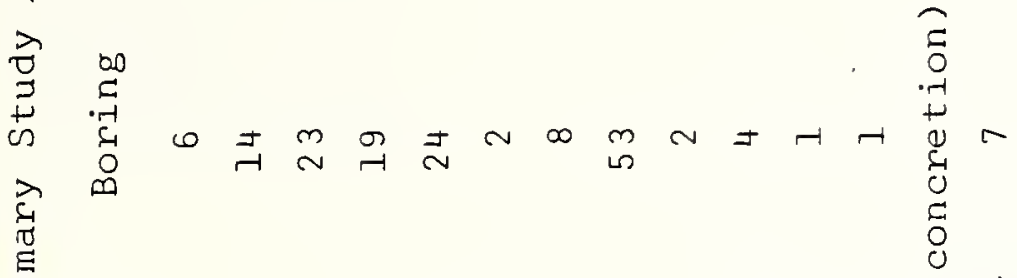

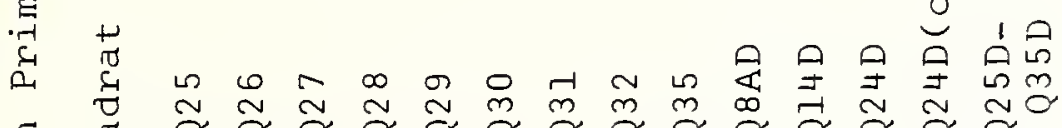

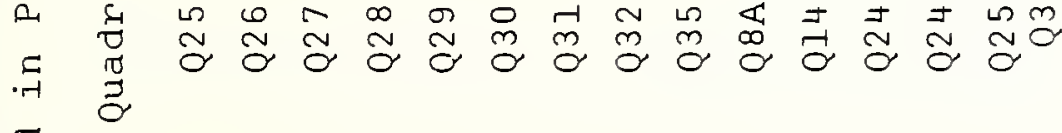

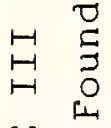

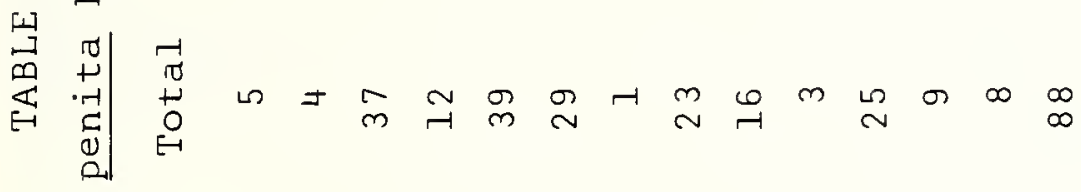

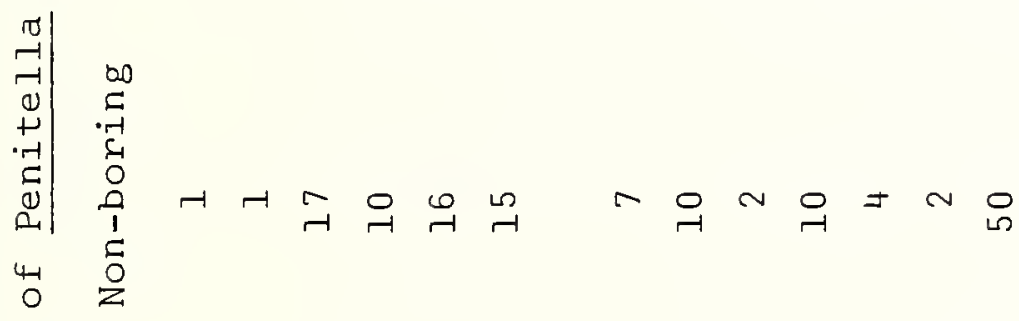

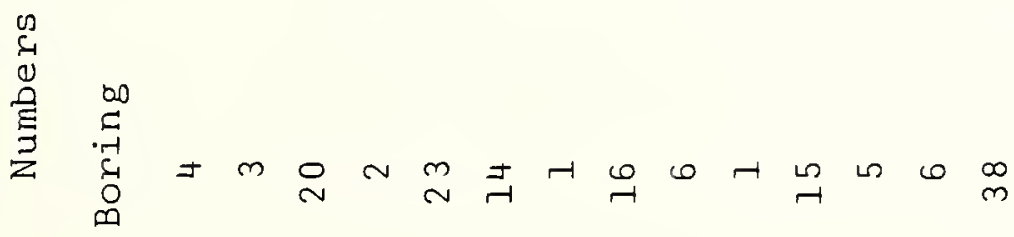

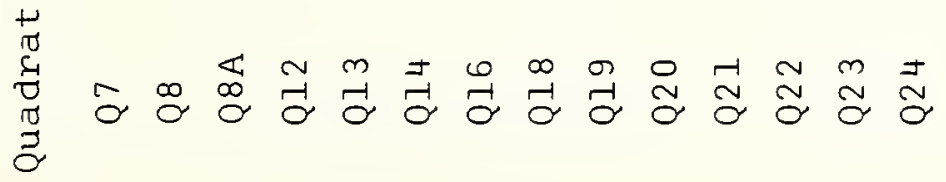





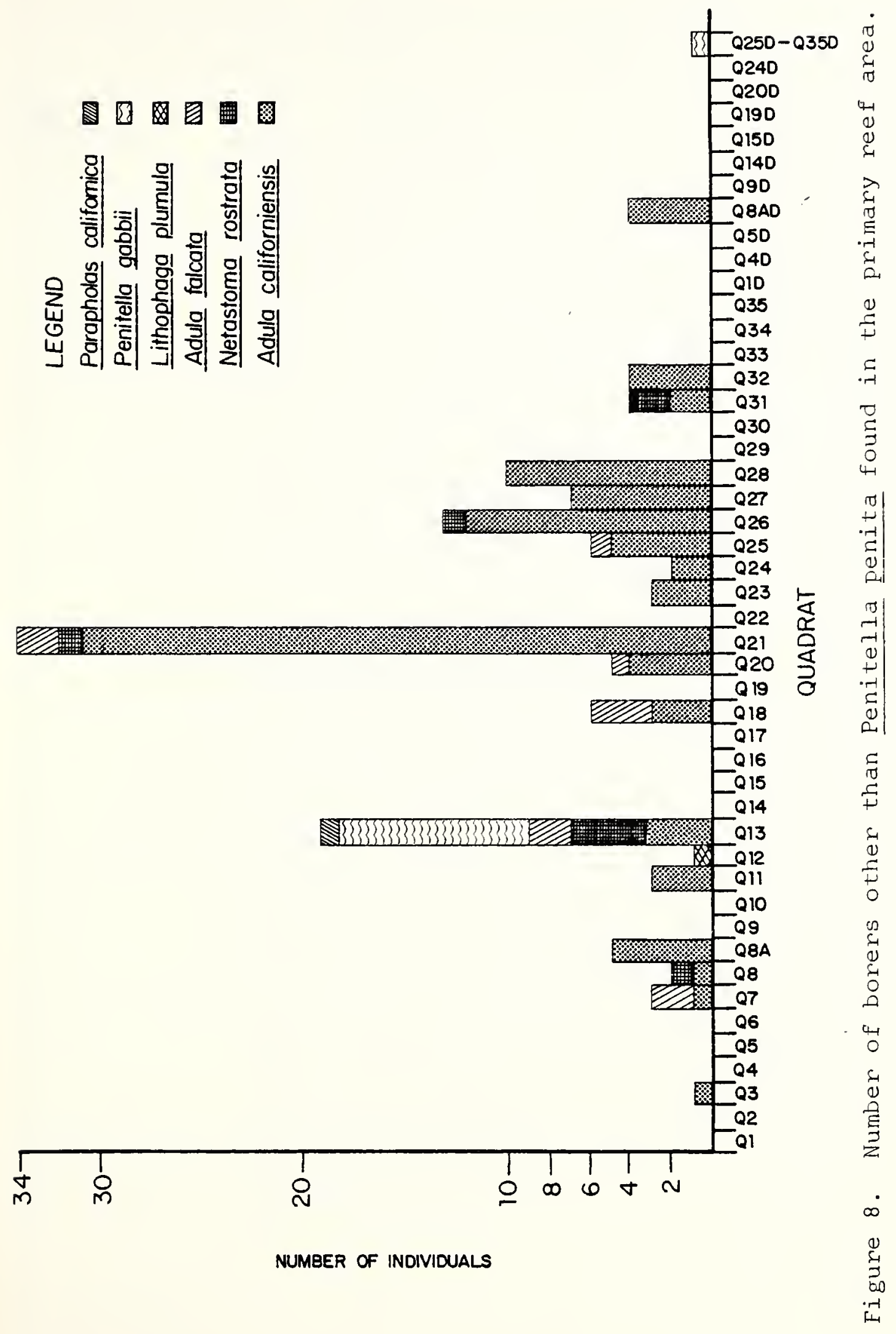



TABLE IV

List of Borers Other Than Penitella penita Found in Primary Reef Area

Quadrat

Q3

Q7

Q8

Q8A

Q11

Q12

Q13

Q18

Q20

Q21

Q2 3

Q24

Q25

Q26

Q27

Q2 8

Q31

Q32

Q8AD

Q25D-Q35D
Species

Adula californiensis

Adula californiensis

Adula falcata

Adula californiensis

Netastoma rostrata

Adula californiensis

Adula californiensis

Lithophaga plumula

Adula californiensis

Adula falcata

Penitella gabbii

Netastoma rostrata

Parapholas californica

Adula californiensis

Adula falcata

Adula californiensis

Adula falcata

Adula californiensis

Netastoma rostrata

Adula falcata

Adula californiensis

Adula californiensis

Adula californiensis

Adula falcata

Adula californiensis

Netastoma rostrata

Adula californiensis

Adula californiensis

Adula californiensis

Netastoma rostrata

Adula californiensis

Adula californiensis

Penitella gabbii
Number

Present

1

1

2

1

1

5

3

1

3

2

8

4

1

3

3

4

1

31

1

2

3

2

5

1

12

1

7

5

2

2

4

4

1 

and Figure 7, a breakdown of the numbers found in each quadrat, show that approximately half of the population was in the young active boring state while about half were in the sexually mature non-boring state ( 318 vs 323 ). The larger populations were found in those quadrats along the western surge channel and the higher sandstone terrace. Figure 30 shows how dense the population of $\underline{P}$. penita can be with in excess of 10 specimens visible in an area $5 x$ $15 \mathrm{~cm}$ ( $1 \mathrm{~cm}$ of surface rock has been removed). Along the surge channel this high population density would be expected since; a) these rocks are wetted with even minor wave conditions, and b) numerous tidepools are present which provide suitable moisture conditions. On top of the terrace in Section III, the substrate is softer and a large tidepool is present, thus one would expect a larger population of borers. The quadrats in Section II are composed of the finer grained siltstone and are wetted at all but the lowest tide conditions thus making a seemingly good environment for borers.

Figure 7 and Table III show that Penitella penita was found in a weathered concretion located in Quadrat Q24D, the only such find in concretions in this study. This concretion was the only rock which had an appreciable amount of $\mathrm{CaCO}_{3}$ (Table VIII).

Figure 8 and Table IV give the numbers of the other species of borers that were found in the reef. The second most common borer was Adula californiensis. This species 

was the most numerous along the top and seaward edge of the soft, large grained sandstone terrace. The other species present in small numbers were Adula falcata, Lithophaga plumula, Penitella gabbii, Parapholas californica, and Netastoma rostrata.

The majority of the Penitella penita removed were burrowing in roughly horizontal directions. As this is the lay of the bedding planes, it is speculated that this direction offers less resistance to boring. It was also noted that the individual $\underline{P}$. penita shells are higniy variable. Some were bent almost $90^{\circ}$ at the siphonoplax end, turning so that an originally vertical burrow at the opening is horizontal at the interior end. Some of the $\underline{p}$. penita shells were short and "dumpy" being almost as wide at the anterior beak end as they were long. Others were almost twice as long as they were wide. This is in agreement with Evan's (1968b) statement that rock hardness affects shell shape and thickness, with harder rock causing more variable and thicker valves.

The size of the Penitella penita covered a large range: 0.2 to $3.2 \mathrm{~cm}$ for boring specimens and 1.1 to $5.7 \mathrm{~cm}$ for non-Doring specimens. The $5.7 \mathrm{~cm}$ adult is probably near the maximum size attainable by $\underline{P}$. penita. Measurements of extended siphons of $\underline{P}$. penita in dishes of running seawater indicate that the siphon can be extended at least 1.5 times the length of the shell. Thus to completely examine an area, locating all specimens (assuming the $5.7 \mathrm{~cm}$ is the 

maximum size) would require removing about $15 \mathrm{~cm}$ of rock, a feat likely to be frowned upon by environmentalists even were it feasible.

Only the live specimens were counted and recorded. Those quadrats on the leading edge of the sandstone terrace as well as some of the quadrats along the western surge channel had numerous dead Penitella penita shells. Also not reponted in Figure 8 was the uncovering of 2 Parapholas californica shells, one in Quadrat 8 and one in Quadrat 13. The shell in Quadrat 8 measured $7.5 \mathrm{~cm}$ long while the shell in Quadrat 13 measured $5.1 \mathrm{~cm}$ across at the beak (anterior) end and $4.5 \mathrm{~cm}$ long with extensive shortening of the shell having occurred because of substrate erosion. Based on the excellent condition of the chitinous flaps at the posterior end of the $7.5 \mathrm{~cm}$ specimen, death was assumed to have occurred within the past few months. Thus, this high intertidal reef environment was capable of sustaining borer life long enough to allow them to attain a large size.

The only other common genus of borers found was Adula, represented primarily by Adula californiensis with a few individuals of Adula falcata. These were found primarily in the softer rock of the sandstone terrace and its seaward edge. The borers Lithophaga plumula, Penitella gabbii, and Netastoma rostrata, while occurring in the area, were somewhat scarce.

The nestler group is composed of six species, the most common ones being Semele rupicola and Hiatella arctica. 

Table $V$ and Figure 9 give a detailed breakdown of species and numbers found. The overall distribution of nestlers parallels that of the borers in that they are most numerous along the western surge channel, upper sandstone terrace, and the terrace's leading edge.

The distribution of borers and nestlers seems to indicate that they prefer an area of fairly frequent inundation by fresh cool ocean water rather than being in a tidal pool where the water stagnates between tidal cycles as well as undergoing considerable warming between tides.

The primary reef is a dynamic area. At the commencement of the observations there was practically no sand on top of the reef and very little at the head of the surge channels. The depth of sand at the head of the surge channel increased by $1 \mathrm{~m}$ in a period of 4 days and then decreased by $I \mathrm{~m}$ in one week. Concurrently with the deposition of sand in the surge channels, Quadrats 1, 2, 3, 5, 6, 7 , and 10 were covered with sand which remained. This might be part of a periodic beach cycle and may explain the sparsity of borers which can have a life span of several years. As the observations progressed, more and more of the reef in sections IV and $V$ became covered with sand. Also quite variable was the quantity of green algae (Chlorophyta) particularly on the upper terrace. At the onset virtually every square centimeter of the terrace was covered by green algae. Toward the beginning of summer (June and July), wind patterns and sea conditions moderated, 



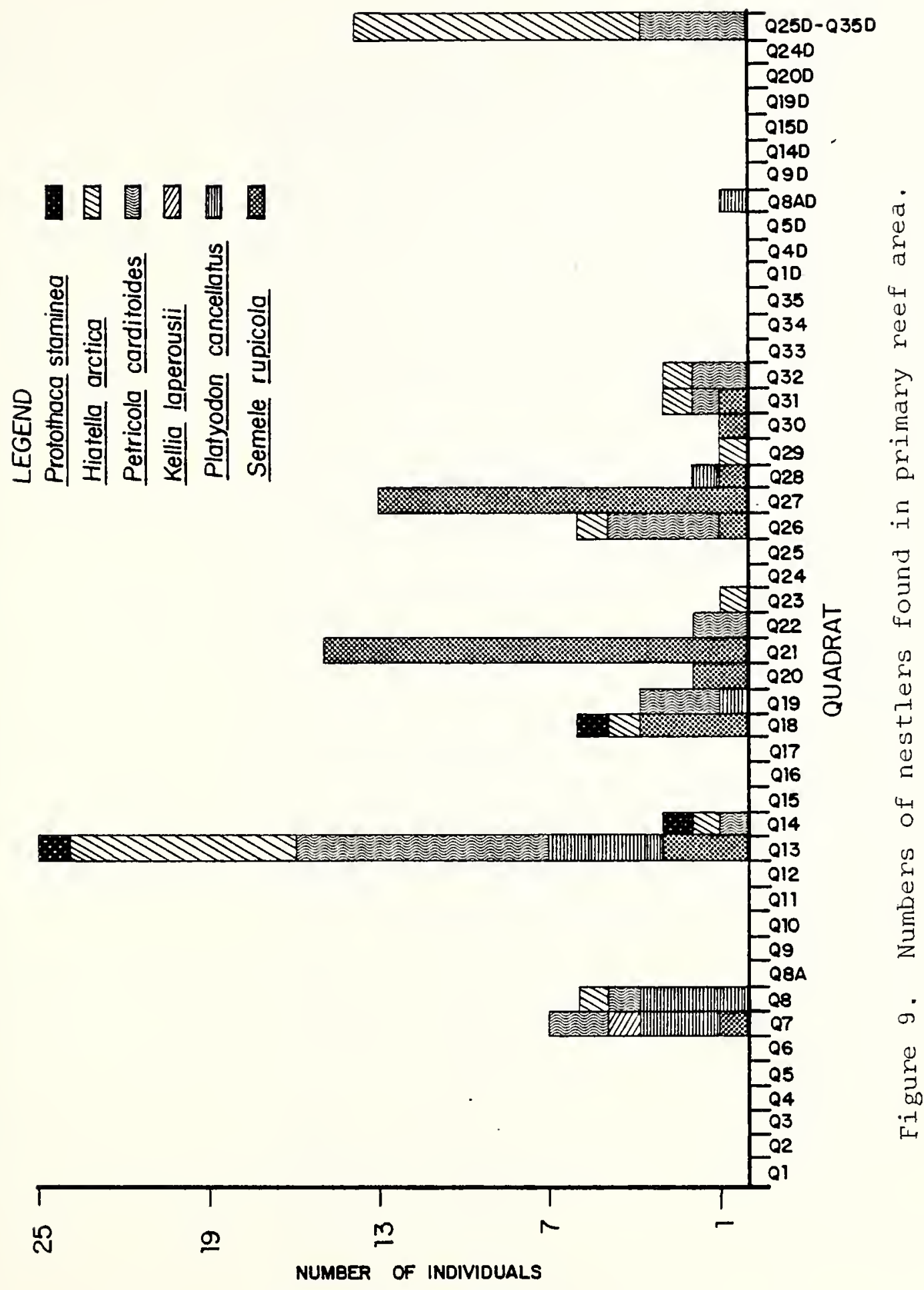



TABLE V

List of Nestlers Found in Primary Reef Area

Quadrat

Q7

Q8

Q13

Q14

Q18

Q20

Q21

Q22

Q23

Q26

Q27

Q28

Q29.

Q30

Q31

Q32

Q8AD

Q25D-Q35D
Species

Petricola carditoides

Semele rupicola

Platvodon cancellatus

Kellia laperousii

Platyodon cancellatus

Petricola carditoides

Hiatella arctica

Platyodon cancellatus

Petricola canditoides

Semele rupicola

Protothaca staminea

Hiatella arctica

Hiatella arctica

Petricola carditoides

Protothaca staminea

Hiatella arctica

Protothaca staminea

Semele rupicola

Number

Present

Petricola carditoides

Platyodon cancellatus

Semele rupicola

Semele rupicola

4

1

1

4

9

3

1

8

1

1

1

1

1

4

3

1

2

15

Petricola carditoides

2

Hiatella arctica

1

Hiatella arctica

Petricola carditoides

Semele rupicola

Semele rupicola

Platyodon cancellatus

Semele rupicola

Hiatella arctica

Semele rupicola

Hiatella anctica

Petricola carditoides

Semele rupicola

1

4

I

13

1

1

1

1

1

1

1

Hiatella arctica

Petricola carditoides

Platyodon cancellatus

Hiatella arctica

Petricola canditoides

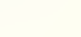

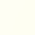

,

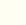

(2)

(a)

(n)

(1)

(1)

3

1

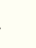

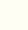

1

4

3

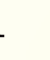

1

1

(1)

1

(1)$$
\text { (1) }
$$$$
0
$$

4 

reducing the amount of reef wetting that occurred. Coupled with this the increased duration and intensity of solar insolation resulted in a rapid disappearance of most of the algae on the terrace leaving barren sandstone.

\section{B. TRANSECT AREA}

The results of the survey for borers in the transect west of Natural Bridges State Beach are presented in Figure 10 and Table VI. Only those quadrats that had borers or nestlers are graphed, or 11 out of 41 quadrats. Borers were found in 10 of these quadrats $(24.4 \%)$ at elevations of I m above MLLW or lower. Again Penitella penita was the most common species of borer with about half in the boring state and half in the non-boring state. The other borers included Adula californiensis, Penitella gabbii, and Netastoma rostrata in much smaller numbers. The nestlers (Figure 11 and $\mathrm{Tab}$ le VII) were represented by only three species, Hiatella arctica the predominant one, Petricola carditoides next, and Semele rupicola the least abundant. They too were found at elevations equal to or less than $1 \mathrm{~m}$ above MLLW.

A detailed study of the epibenthic animals and plants was not conducted. From a cursory look at each of the quadrats, the dominant animals on the terrace were large beds of mussels, Mytilus californianus, Quadrat N-1 to N-18. Anthopleura elegantissima was found in several of the tidepools landward to Quadrat $\mathrm{N}-19$. The plants above Quadrat N-32 consisted of dead and deteriorating Enteromorpha linza. 



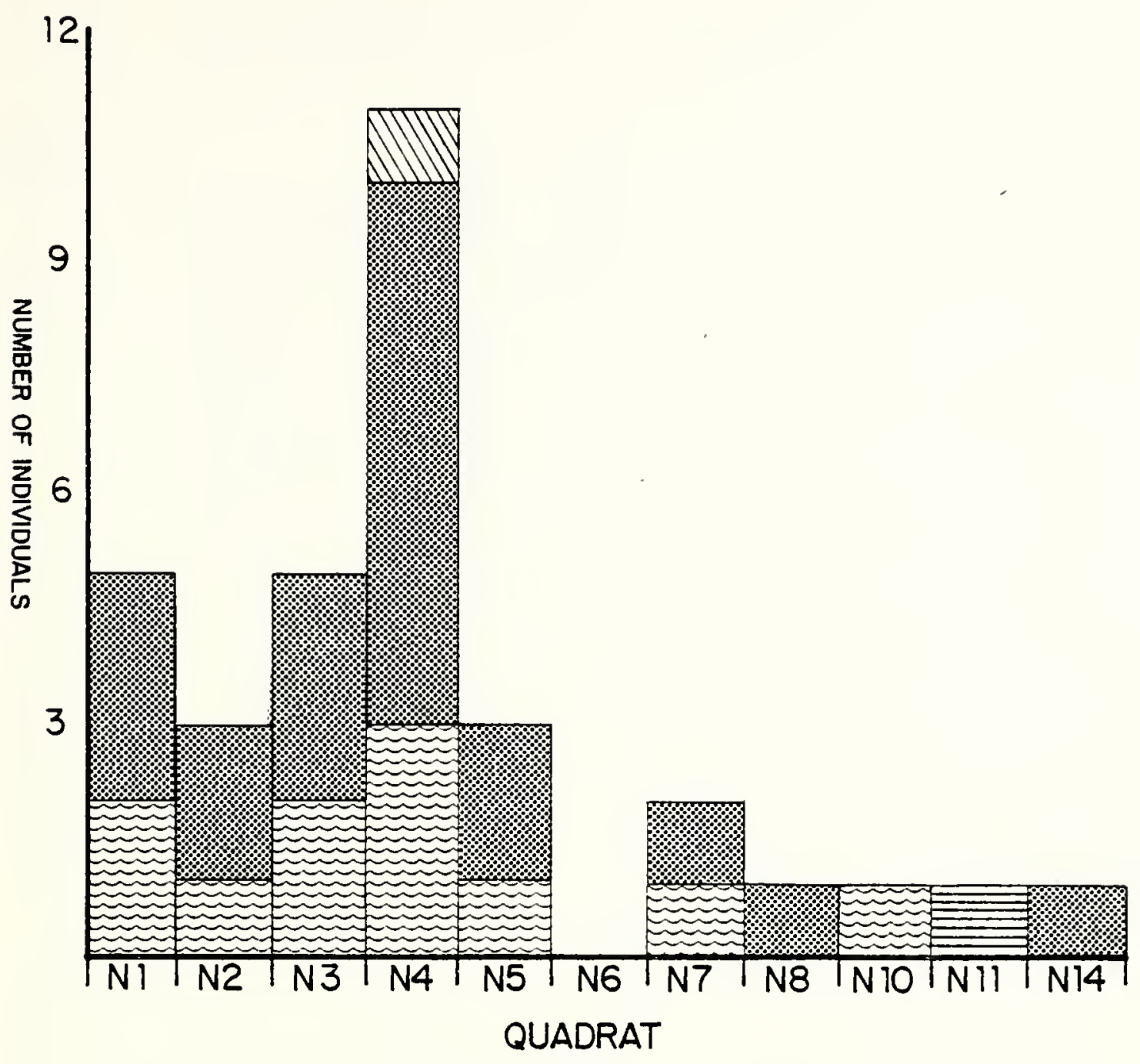

\section{LEGEND}

Penitella gabbii

जणाण

Netastoma rostrata

Penitella penita (non-boring)

Penitella penita (boring)

Figure 10. Numbers of borers found in transect study area. 



\author{
TABLE VI \\ List of Borers Found in Transect Area
}

Quadrat

N1

N2

N3

N4

N5

N7

N8

N10

$\mathrm{N} 11$

N14
Species

Penitella penita (boring)

Penitella penita (non-boring)

Penitella penita (boring)

Penitella penita (non-boring)

Penitella penita (boring)

Penitella penita (non-boring)

Penitella penita (boring)

Penitella penita (non-boring)

Penitella gabbii

Penitella penita (boring)

Penitella penita (non-boring)

Penitella penita (boring)

Penitella penita (non-boring)

Penitella penita (non-boring)

Penitella penita (boring)

Netastoma rostrata

Penitella penita (non-boring)
Number

Present

2.

3

1

2

3

2

3

7

1

1

2

1

1

1

1

1

1 



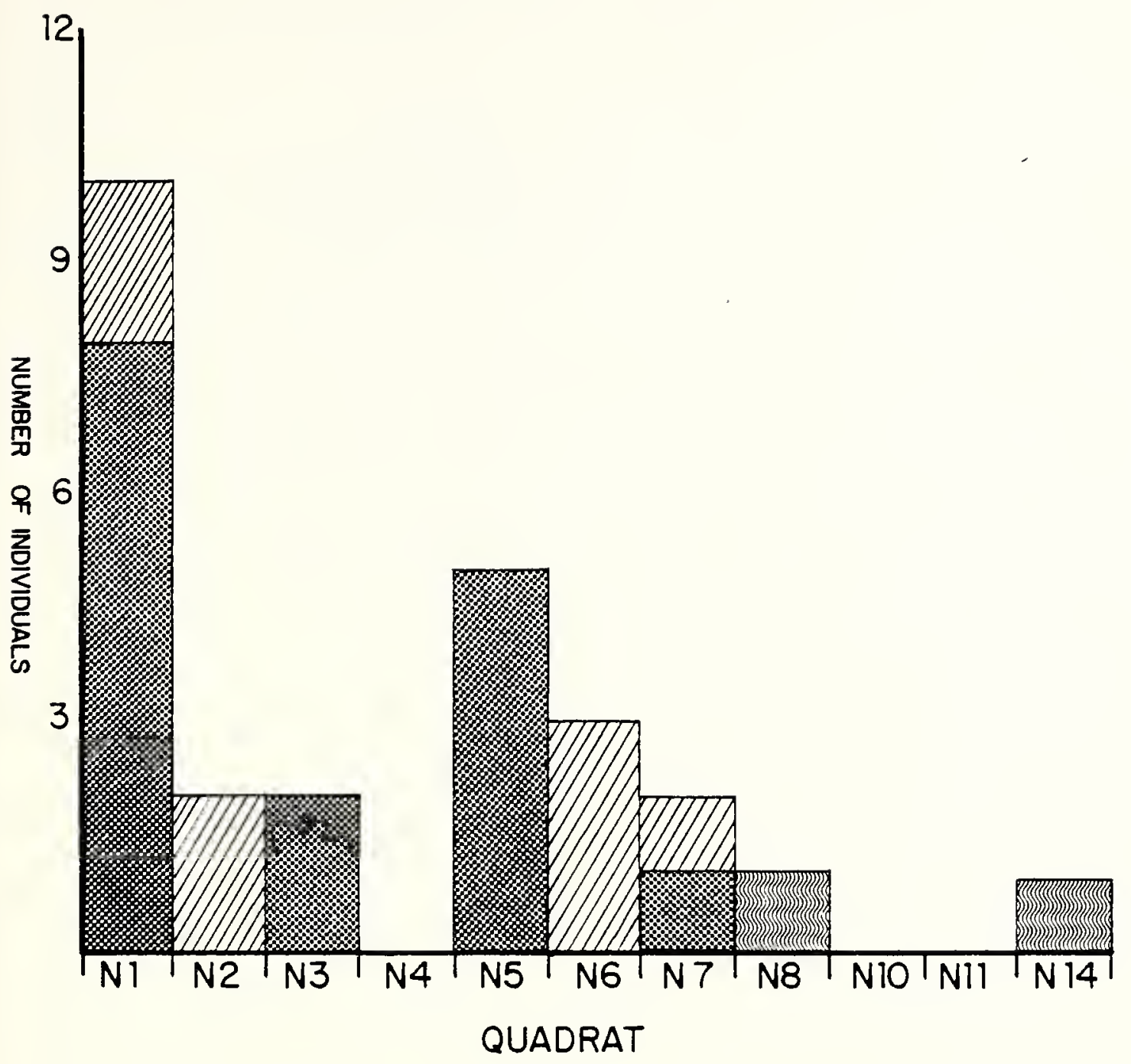

LEGEND

Semele rupicola

Petricola carditoides WIII

Hiatella arctica 沙

Figure 11. Numbers of nestlers found in transect study area. 



\section{TABLE VII}

List of Nestlers Found in Transect Study Area

Quadrat

NI

$\mathrm{N} 2$

N3

N5

N6

N7

N8

N14
Species

Hiatella arctica Petricola carditoides Petricola carditoides Hiatella arctica Hiatella arctica Petricola carditoides Hiatella arctica Petricola carditoides Semele rupicola Semele rupicola
Number Present 

From Quadrat N-4 through N-32 live Enteromorpha linza patches were found while Gigartina papillata was found from Quadrat $N-7$ to $N-32$. The quadrats from $N-1$ through N-Il supported Iridaea flaccida, Egregia menziesii, Phyllospadix scouleri, Pterosiphonia bipinnata, Chaetomorpha linum, and Ulva lobata in varying numbers. Some Rhodoglossum affine was found in Quadrats N-30 through N-32.

C. UNDERWATER SURVEY

The primary result of the dives was the observation that there are few rock outcroppings of any size. The bottom is generally flat with isolated rocky patches that protude above the bottom, usually less than $0.5 \mathrm{~m}$. These outcroppings are entirely covered with algae, particularly kelp. Those surfaces that were cleaned of algal growth appeared to resemble the chert of the intertidal terrace. Efforts to quarry portions of the rock for investigation generally proved fruitless because of the reduced hammering effectiveness in the water and the rock hardness. Those small pieces that were broken off yielded no borens and only 1 Hiatella anctica.

A second finding that has a major impact on the distribution of rock borers was the vast coverage of sand on the ocean floor, with even the depressed areas around kelp holdfasts sand filled.

While swimming through the surf zone, an area was observed that had been swept free of sand. This one area was a flat surface of siltstone that was free of any 

attached plants. Evident on the surface were indentations characteristic of the pholad holes found in other rocks in the intertidal regions. Surge in the surf zone however prevented the divers from conducting closer examinations.

\section{CARBONATE ANALYSIS}

The results of the carbonate analyses are listed in Table VIII which gives the amount of inorganic carbon measured as $\mathrm{CO}_{2}$ and the amount of carbonate calculated. It is evident that with the exception of the concretion and one rock sample, there are extremely small amounts of $\mathrm{CaCO}_{3}$, i.e. $<0.8 \% \mathrm{CaCO}_{3}$. This indicates that the borers are probably dependent on some other means of boring than chemical dissolution of rock substrate or cementing agent. This poses an interesting and unresolved question because some of the rock is extremely hard, resisting excavation efforts using a 2 pound sledge hammer and chisel. Hardness tests were not conducted since there is no universally acceptable method for testing sedimentary rocks as hardness depends not only on the individual constituents but also the cementing agent.

\section{E. PETROGRAPHIC ANALYSIS}

Florence Lee-Wong of the U. S. Geological Survey provided the following petrographic analysis of the chert sample from Section $V$ of the reef:

Source: Monterey formation

Name: Silty Biogenic Chert

Composition: 90-95\% siliceous biogenic hash-radiolaria, 



\section{TABLE VIII}

Table of Inorganic Carbon, Carbonate and Assumed

Calcium Carbonate Content of Various Rock Samples

\begin{tabular}{|c|c|c|c|}
\hline Quadrat & $\begin{array}{c}\text { Percent } \\
\text { inorganic } \\
\text { carbon }\end{array}$ & $\begin{array}{l}\text { Percent } \\
\text { car- } \\
\text { bonate }\end{array}$ & $\begin{array}{c}\text { Percent } \\
\text { calcium } \\
\text { carbonate }\end{array}$ \\
\hline Q8 & 0.05 & 0.23 & 0.38 \\
\hline Q8 & 0.09 & 0.45 & 0.74 \\
\hline Q12 & 0.03 & 0.14 & 0.24 \\
\hline Q13 & 0.01 & 0.05 & 0.08 \\
\hline Q18 & 0.01 & 0.07 & 0.11 \\
\hline Q19 & 0.09 & 0.43 & 0.72 \\
\hline Q22 & 0.01 & 0.07 & 0.12 \\
\hline Q2 3 & 0.01 & 0.05 & 0.08 \\
\hline Q24 & 0.01 & 0.04 & 0.07 \\
\hline Q24D & 0.07 & 0.37 & 0.61 \\
\hline Q24D & 0.62 & 3.09 & 5.16 \\
\hline Q24D(concretion) & 9.82 & 49.10 & 81.84 \\
\hline Q2 5 & 0.04 & 0.21 & 0.36 \\
\hline Q25 & 0.01 & 0.05 & 0.09 \\
\hline Q26 & 0.02 & 0.08 & 0.14 \\
\hline Q26 & 0.03 & 0.14 & 0.24 \\
\hline Q27 & 0.03 & 0.15 & 0.26 \\
\hline Q28 & 0.04 & 0.19 & 0.32 \\
\hline Q30 & 0.05 & 0.25 & 0.42 \\
\hline Q31 & 0.01 & 0.03 & 0.04 \\
\hline Q32 & 0.03 & 0.14 & 0.23 \\
\hline Q35 & 0.02 & 0.11 & 0.19 \\
\hline Q29D-Q35D & 0.03 & 0.16 & 0.27 \\
\hline NI & 0.03 & 0.16 & 0.27 \\
\hline N2 & 0.01 & 0.07 & 0.11 \\
\hline N3 & 0.03 & 0.14 & 0.23 \\
\hline N4 & 0.09 & 0.44 & 0.74 \\
\hline N5 & 0.03 & 0.16 & 0.27 \\
\hline N6 & 0.02 & 0.12 & 0.20 \\
\hline N7 & 0.05 & 0.23 & 0.38 \\
\hline N8 & 0.05 & 0.24 & 0.39 \\
\hline NII & 0.03 & 0.17 & 0.28 \\
\hline N1I & 0.02 & 0.11 & 0.19 \\
\hline N1 4 & 0.003 & 0.016 & 0.027 \\
\hline
\end{tabular}



sponge spicules, diatoms, etc.

$5-8 \%$ silt-sized detrital rock and

mineral fragments-quartz, feldspar,

biotite, magnetite, hematite,

microcrystalline chert; no cementa-

tion present

Lacking cementation, it is speculated that the overburden compressed the sediment forming the rock. There appears to be one possible explanation of how the pholads can burrow into this siliceous material, i.e., they work loose the individual constituents rather than just bore through them.

\section{F. GENERAL DISCUSSION}

It is evident to anyone familiar with both the northern and southern intertidal coastlines of Monterey Bay that the southern region has a much more diversified fauna and flora as well as a much larger total biomass. A particularly important result of this study is the discovery that Penitella penita is extremely common in the intertidal zone even to heights of $2+\mathrm{m}$ above MLLW. As mentioned previously, bivalve borers are not found in the intertidal area of the southern part of Monterey Bay on the Monterey Peninsula, probably as a result of the granitic rock outcropping along the coast.

A question discussed by biologists is whether the bivalves are boring chemically or mechanically. Warme et al. (1971) reported Adula californiensis and Lithophaga plumula boring into rock in the Scripps Canyon wall which contained 

as little as $5 \%$ calcium carbonate. This thesis presents the first analysis of rocks bored in Monterey Bay. The low values of $\mathrm{C}_{a} \mathrm{CO}_{3}$ (Table VIII) give credance to the theory that bivalve boring is mechanical. A question yet to be answered is how they can Eurrow into the siliceous chert which is evidently harder than their shell.

The borers found in the intertidal regions in this study differ from those borers found by Addicott (1966) in the fossiliferous sandstone 5 meters above MLLW a short distance away. It is unknown whether this represents a truly different population due to environment or whether it is due to preservation peculiarity. 

Warme, et al. (1971) reported that the Scripps Submarine Canyon was today being eroded more by bioerosion than physical and chemical erosion and weathering. They estimated the bioerosion of the canyon wall by all marine invertebrates at approximately $10 \mathrm{~mm}$ per year. Evans (1968c) did a detailed study of the erosion at Coos Bay, Oregon, where Penitella penita are very prevalent which showed the erosion to be 12 millimeters per year. Reid (1907) estimated that the chalky subtidal benches off the Norfolk coast in England were eroding at the rate of $25 \mathrm{~mm}$ per year.

During the period of observations, several large blocks of chert at the primary reef site were broken loose by wave action resulting in a noticeable retreat of the upper chert layer in Sections IV and $V$ towards the cliff. Blocks as large as $2 \times 1 \times 0.3$ meters were observed to be broken loose and tossed up to the base of the cliff. In the five months of observations, the retreat amounted to in excess of 2 meters, exposing substantial areas of the softer siltstone that had been bored on exposed edges by Penitella penita (Figure 31). It thus appears that the burrowing of the pholads hastened the erosion by causing weak spots in the rock upon which the waves could act more effectively. 



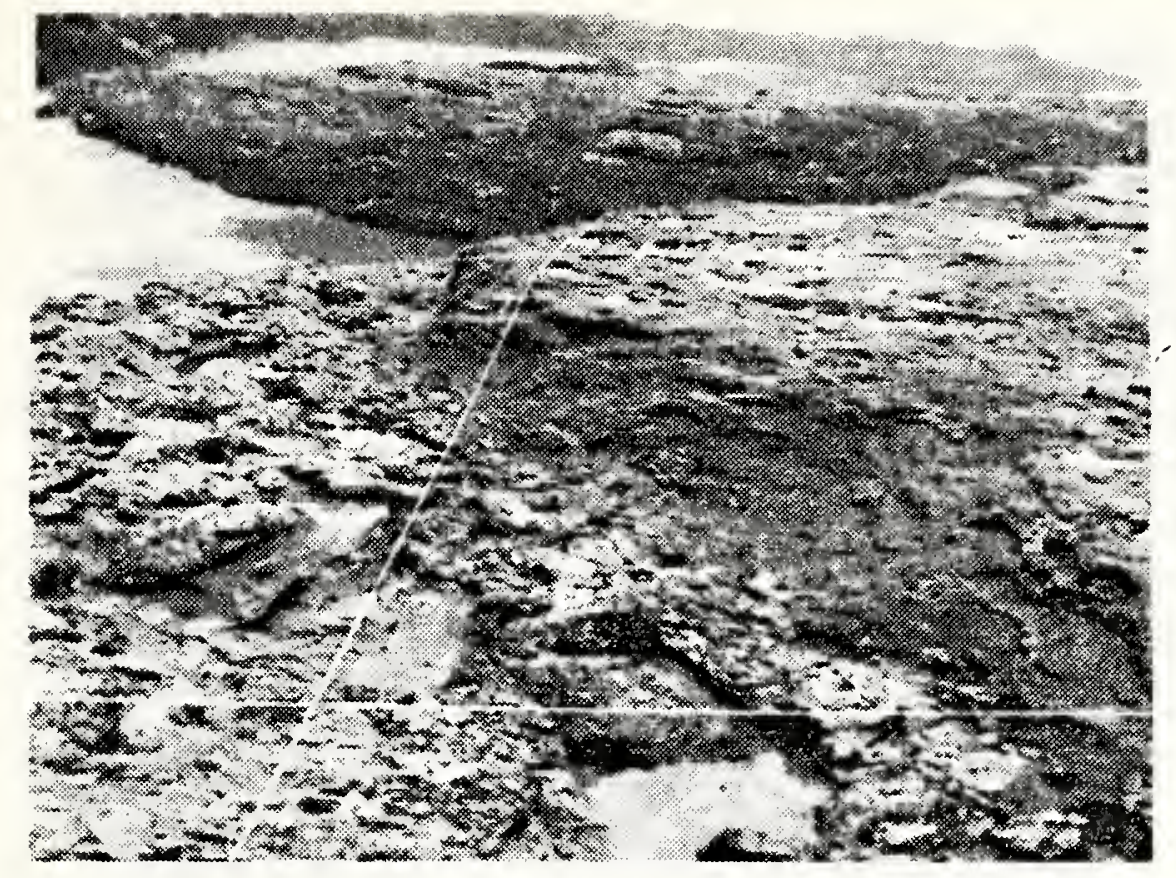

Figure 12. Photo of sandstone terrace (Section III) on right and Sections IV and $V$ on left. Photo is looking east across primary reef area.

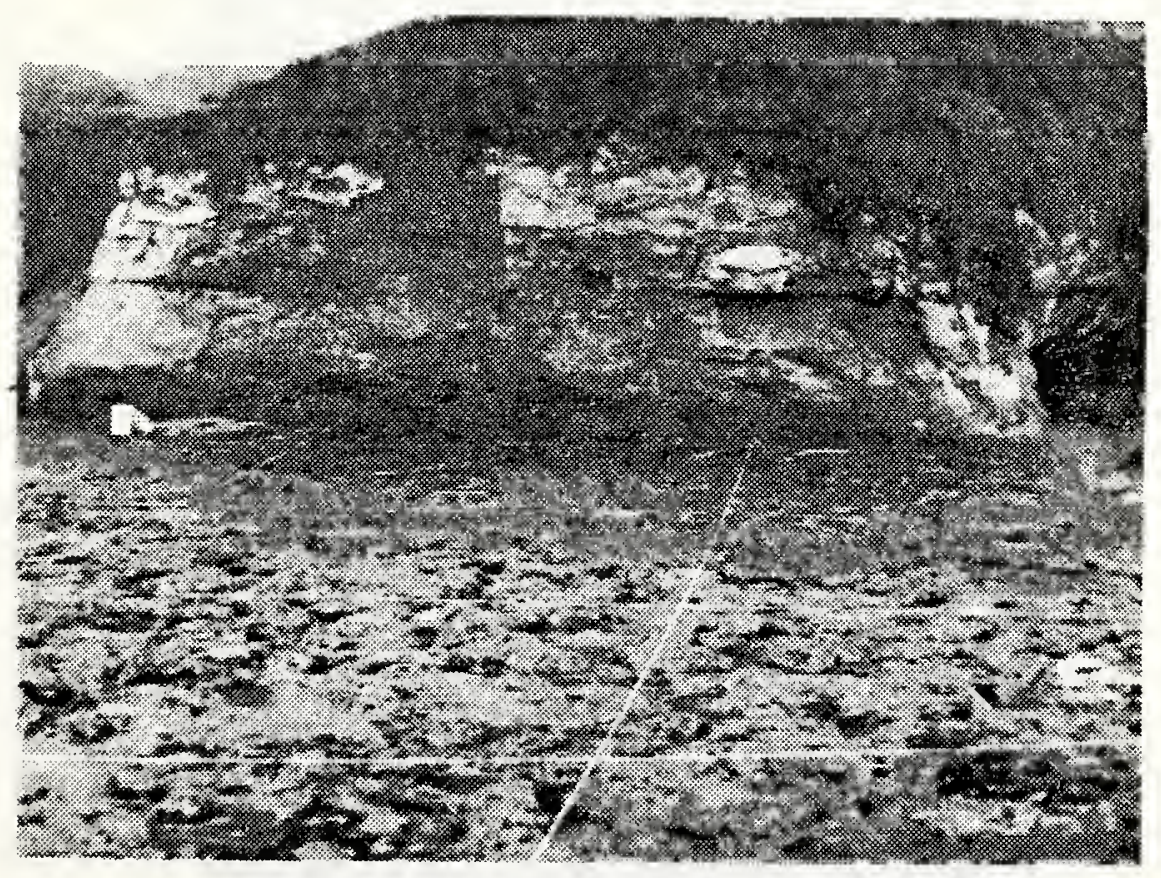

Figure 13. Photo of primary reef area looking from Section III across Sections IV and $V$ towards mudstone cliff. Photo shows relatively level but irregular surface of section $V$. 



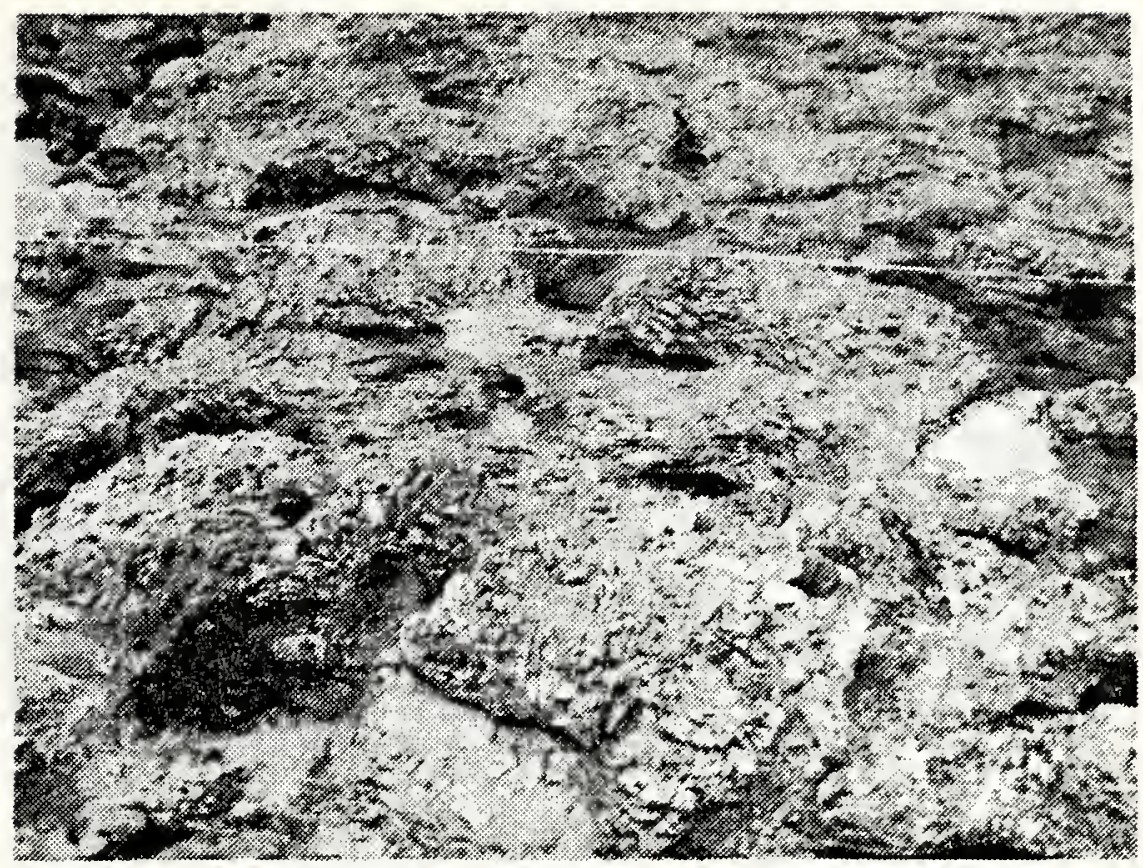

Figure 14. Photo of Section $V$ of primary reef area showing tidepools formed in chert. Note highly convoluted and fractured nature of chent.

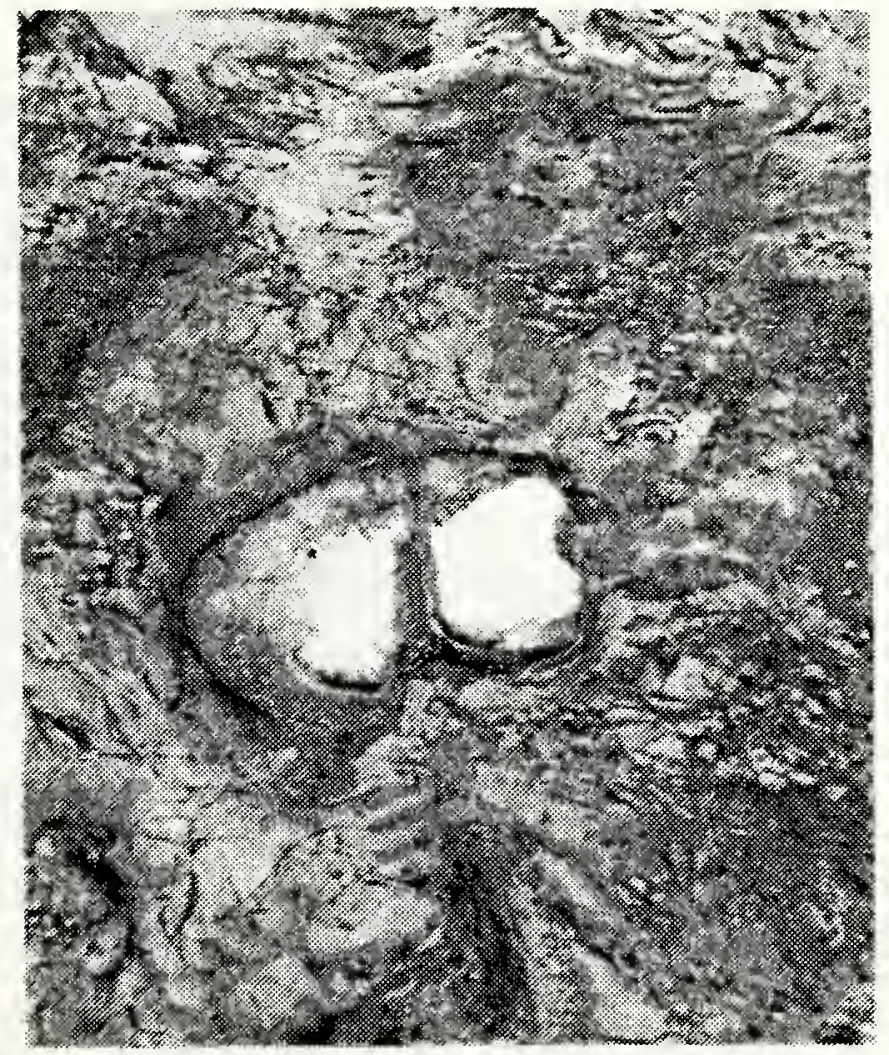

Figure 15. Photo of chert in Section $V$ of primary reef area showing convoluted and fractured nature. Note concretion. 



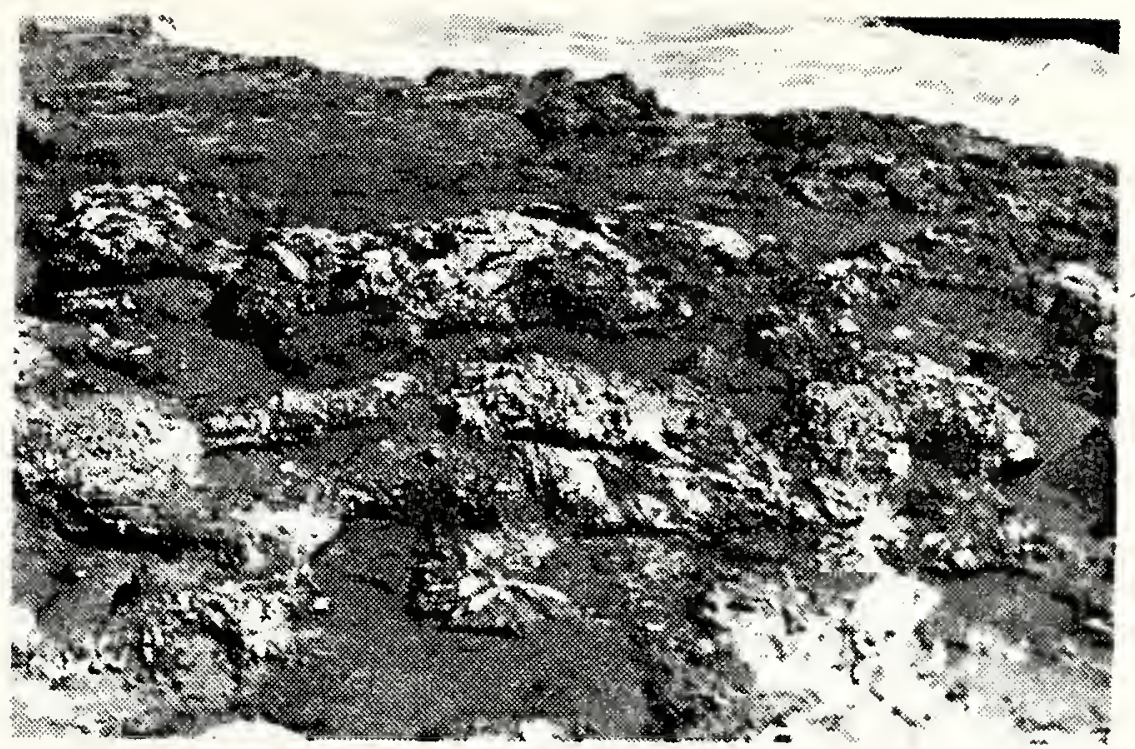

Fi-gure 16. Photo of section $V$ of primary reef area showing region of severe wave attack and area of flat siltstone (upper left hand corner of photo).

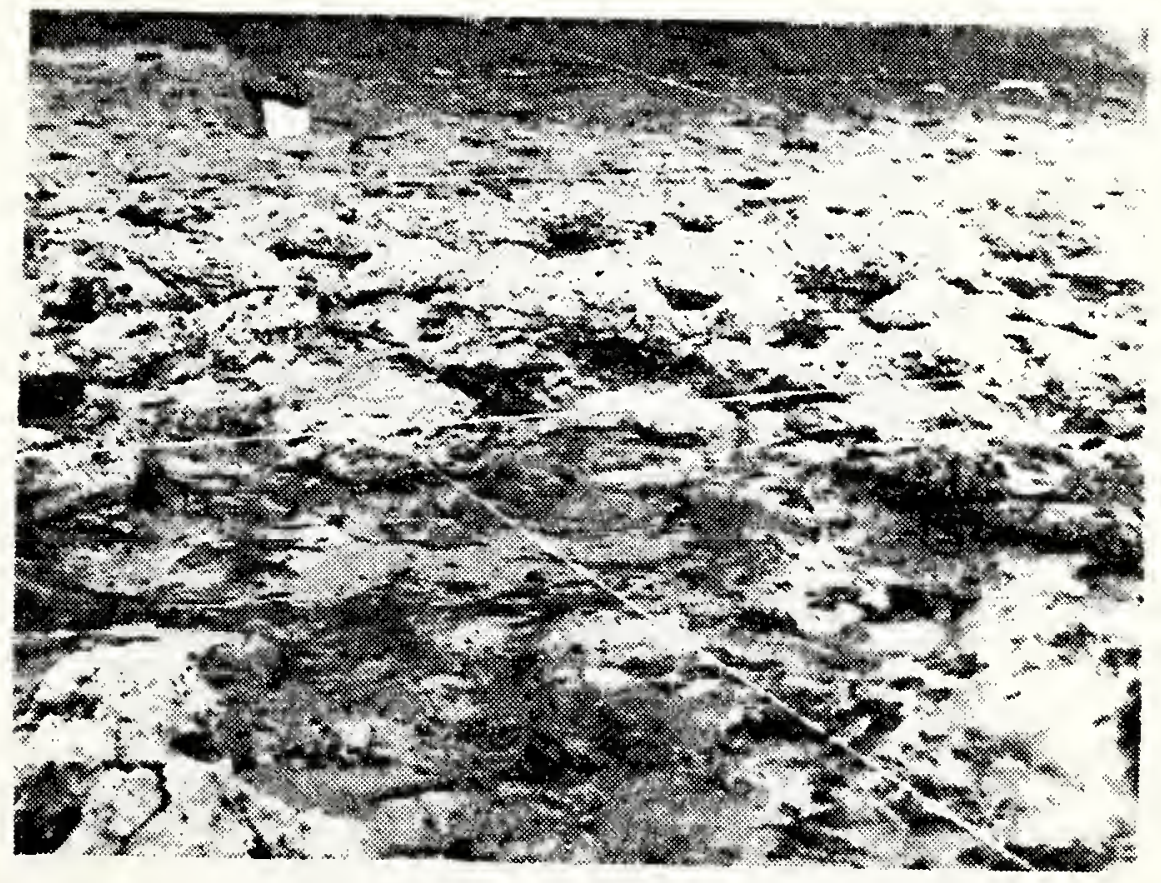

Figure 17. Photo of section $V$ of primary reef area showing area of severe erosion of chert, flat siltstone region, and tidepools in chert. 



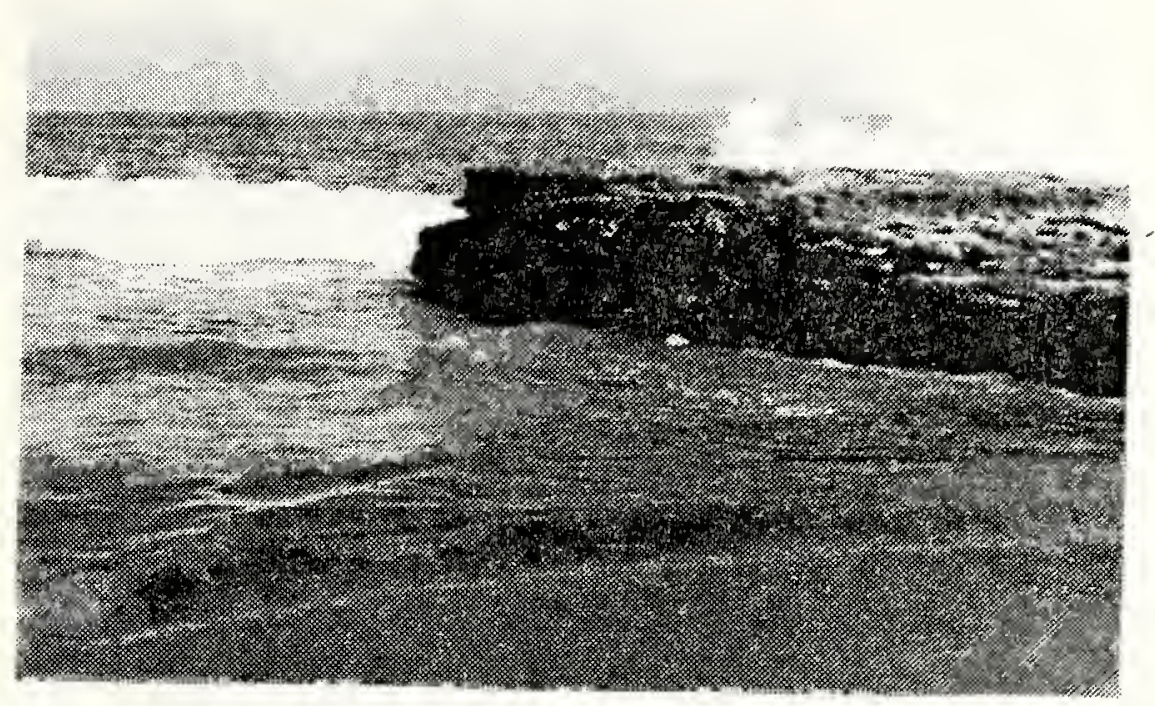

Figure 18. View of vertical face of primary reef area looking across eastern surge channel.

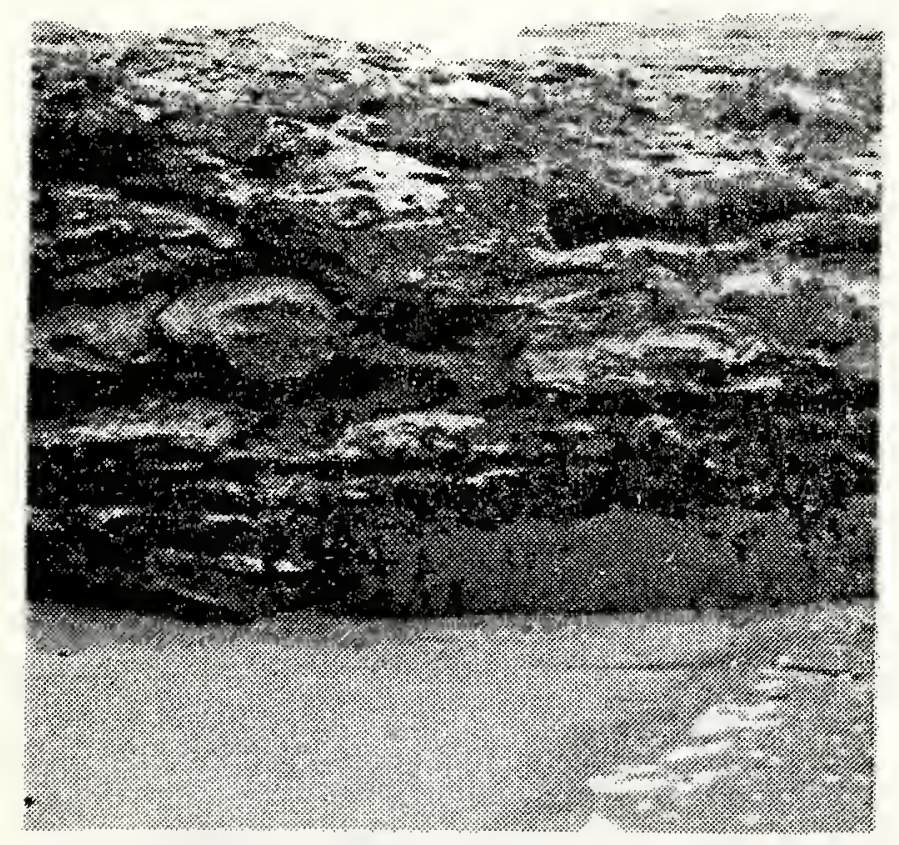

Figure 19. View of vertical face of primary reef area as seen across western surge channel. Note concretion in center left side of photo. 



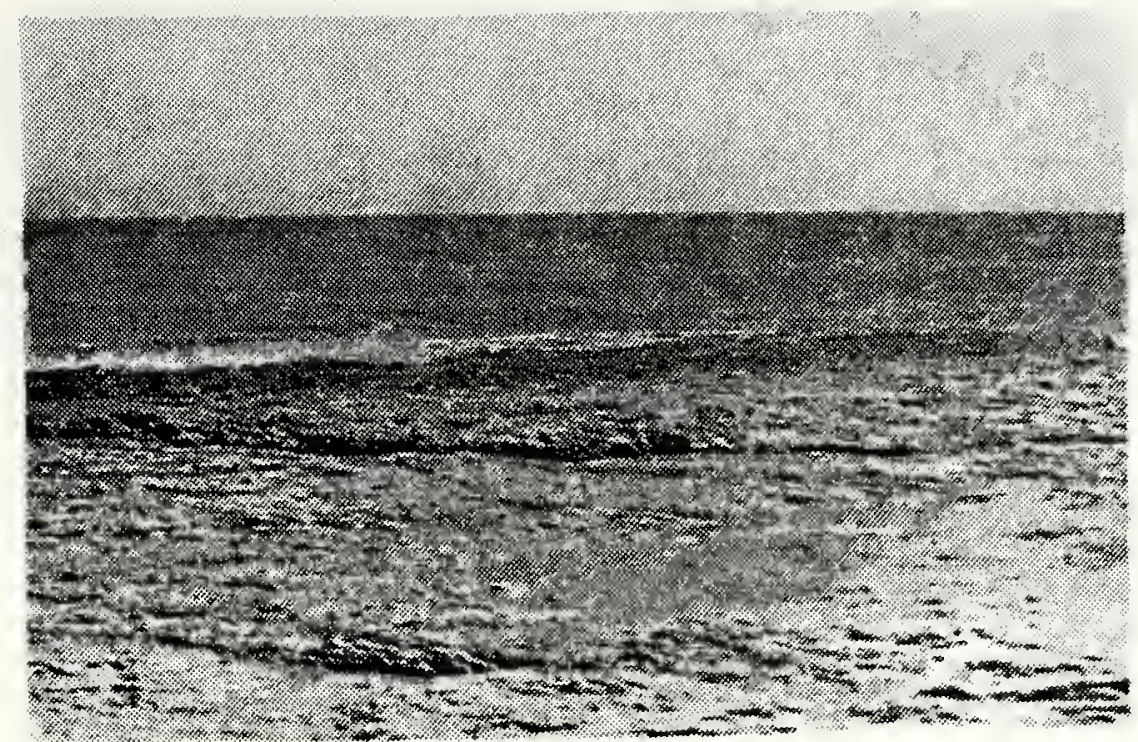

Figure 20. View of flat intertidal area chosen for transect study area.
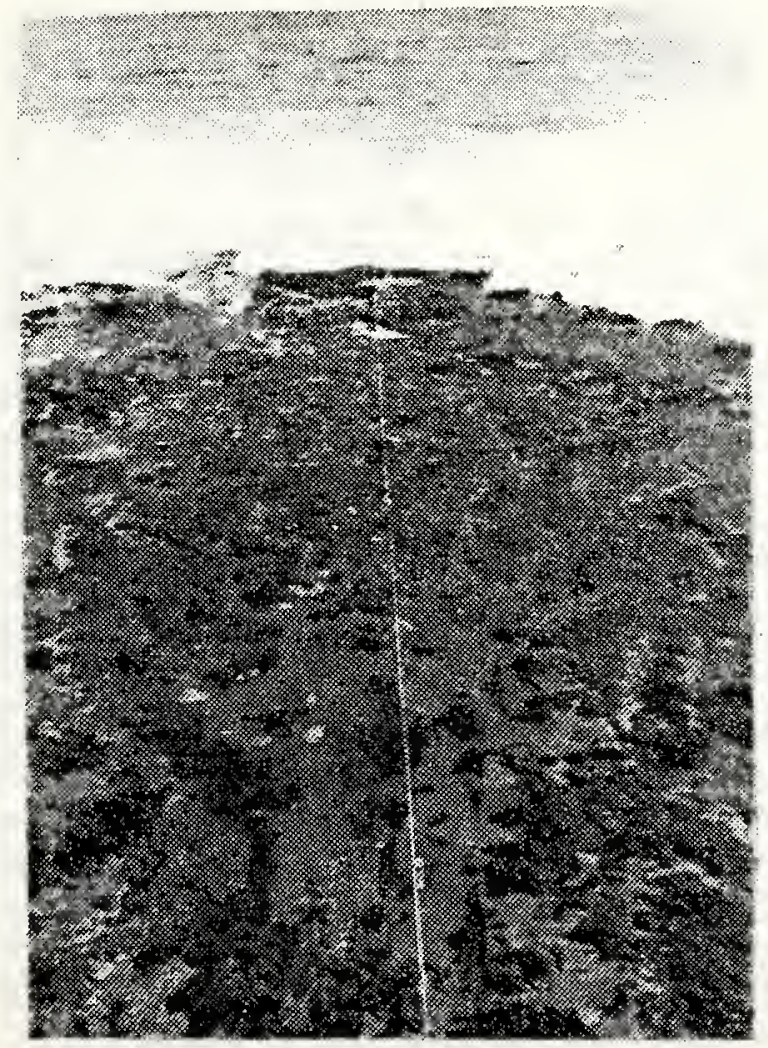

Figure 21. View of transect study area showing tidepools at lower level. 



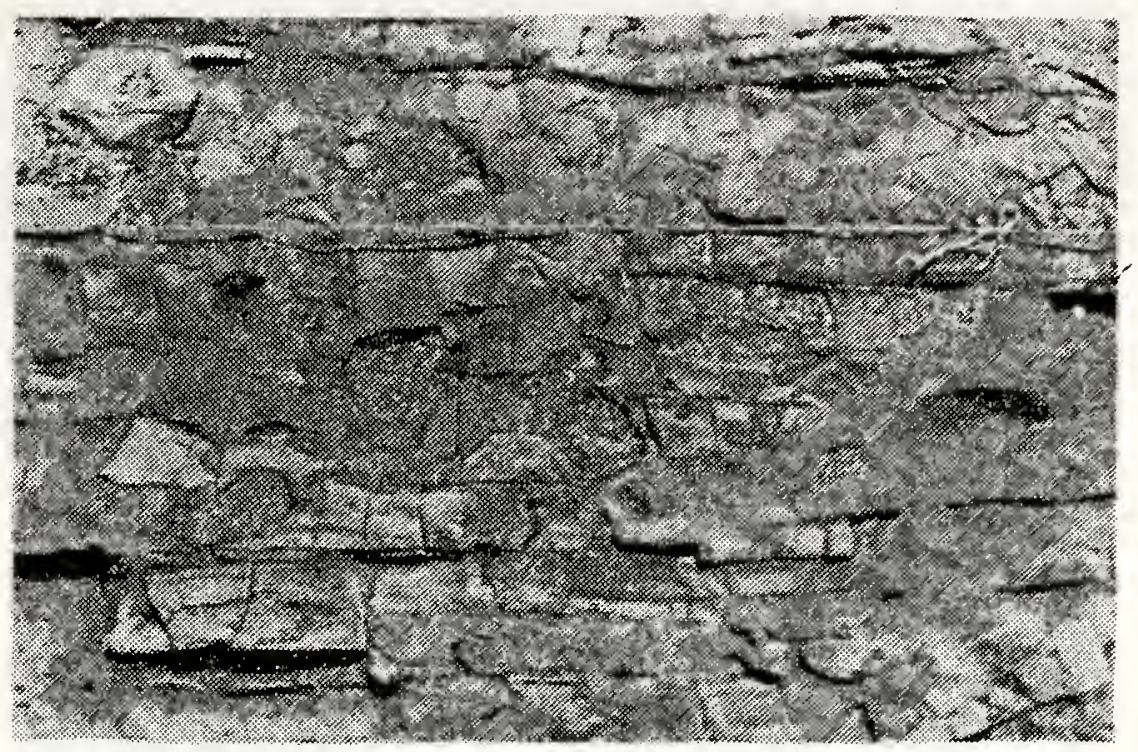

Figure 22. View of rock in high region of transect study area showing fractured nature.

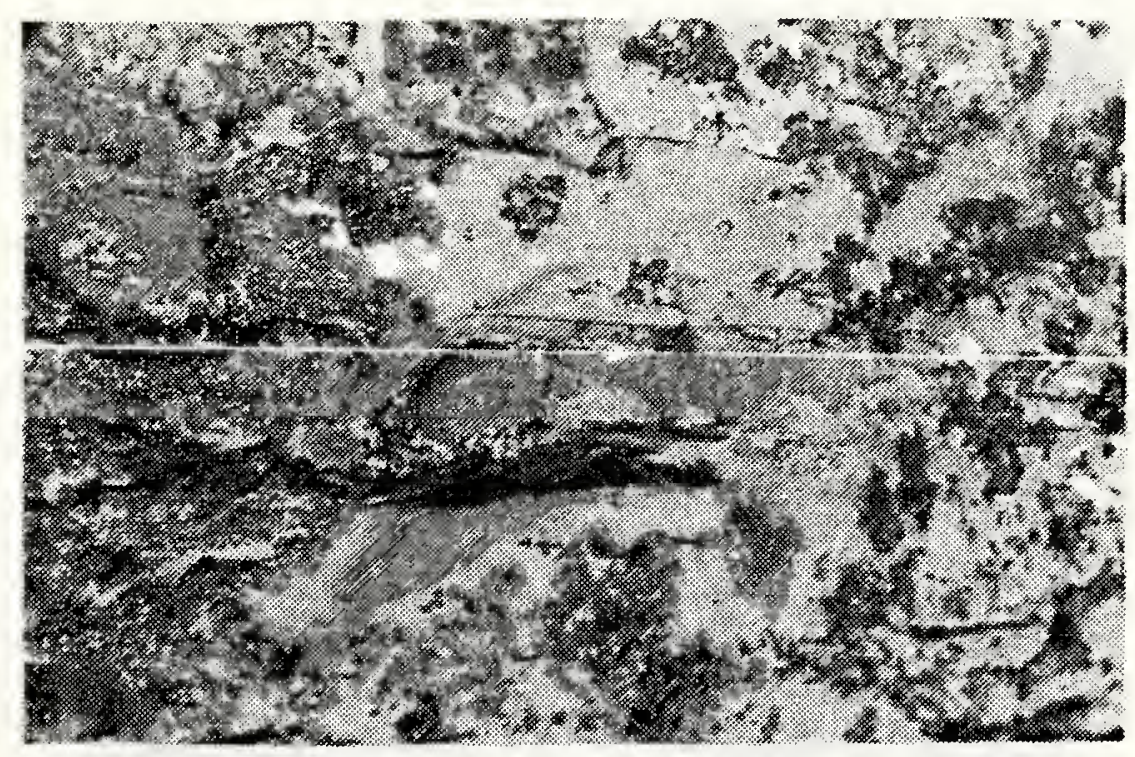

Figure 23. View of rock in low region of transect study area showing unfractured nature. 



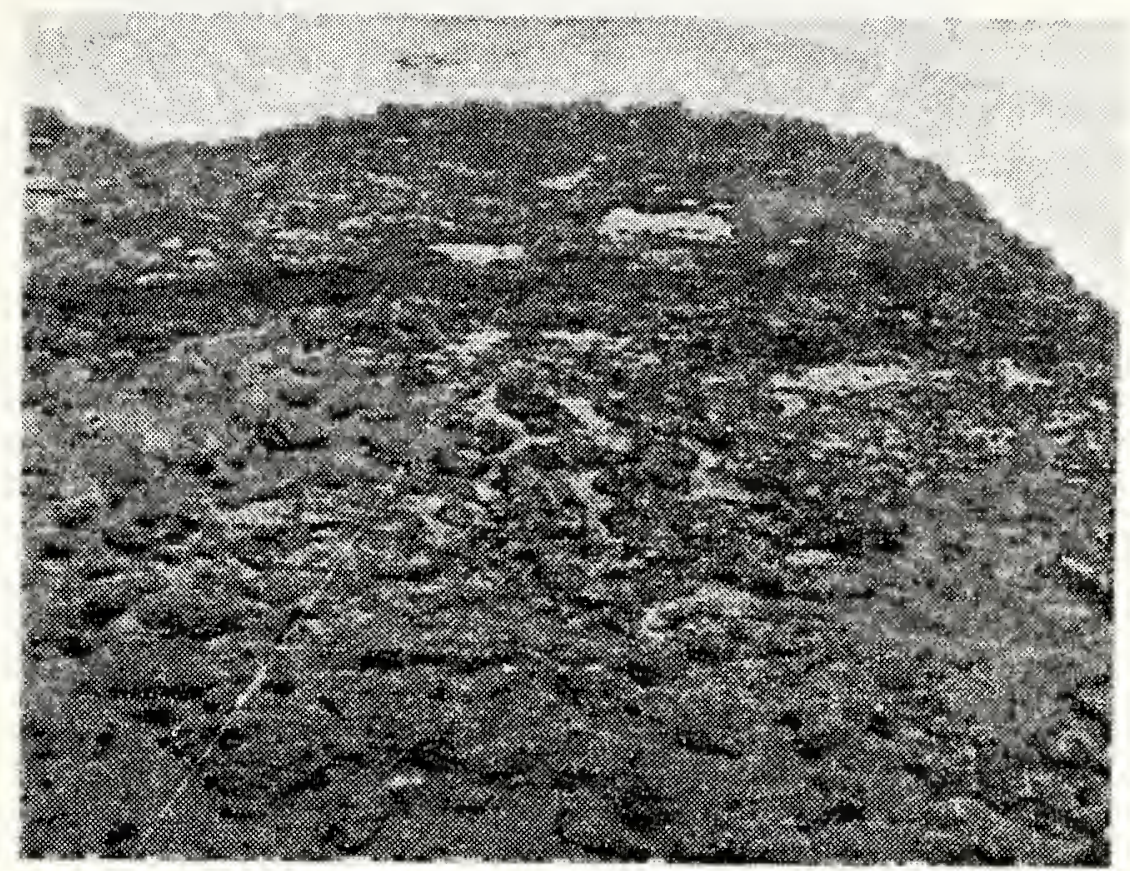

Figure 24. View from top of cliff overlooking primary reef area showing method of quadrat marking on upper surface.

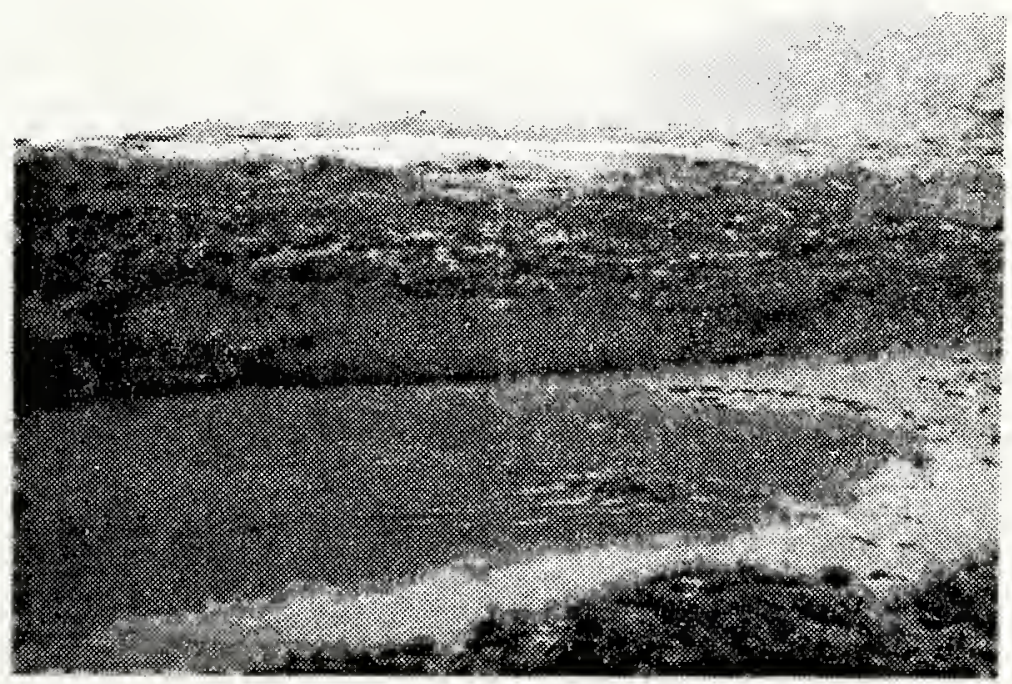

Figure 25. View of primary reef area across eastern surge channel showing method of marking vertical faces. 



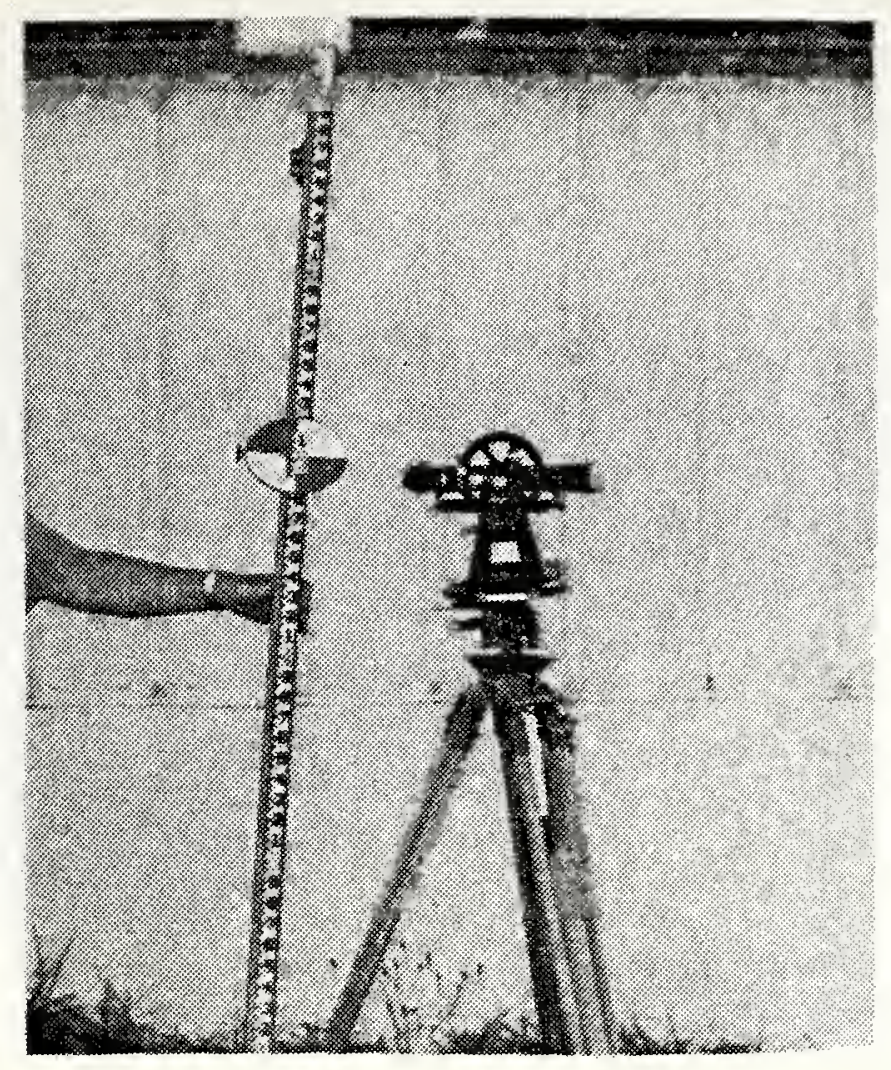

Figure 26. Equipment used to determine elevations above Mean Lower Low Water (MLLW).

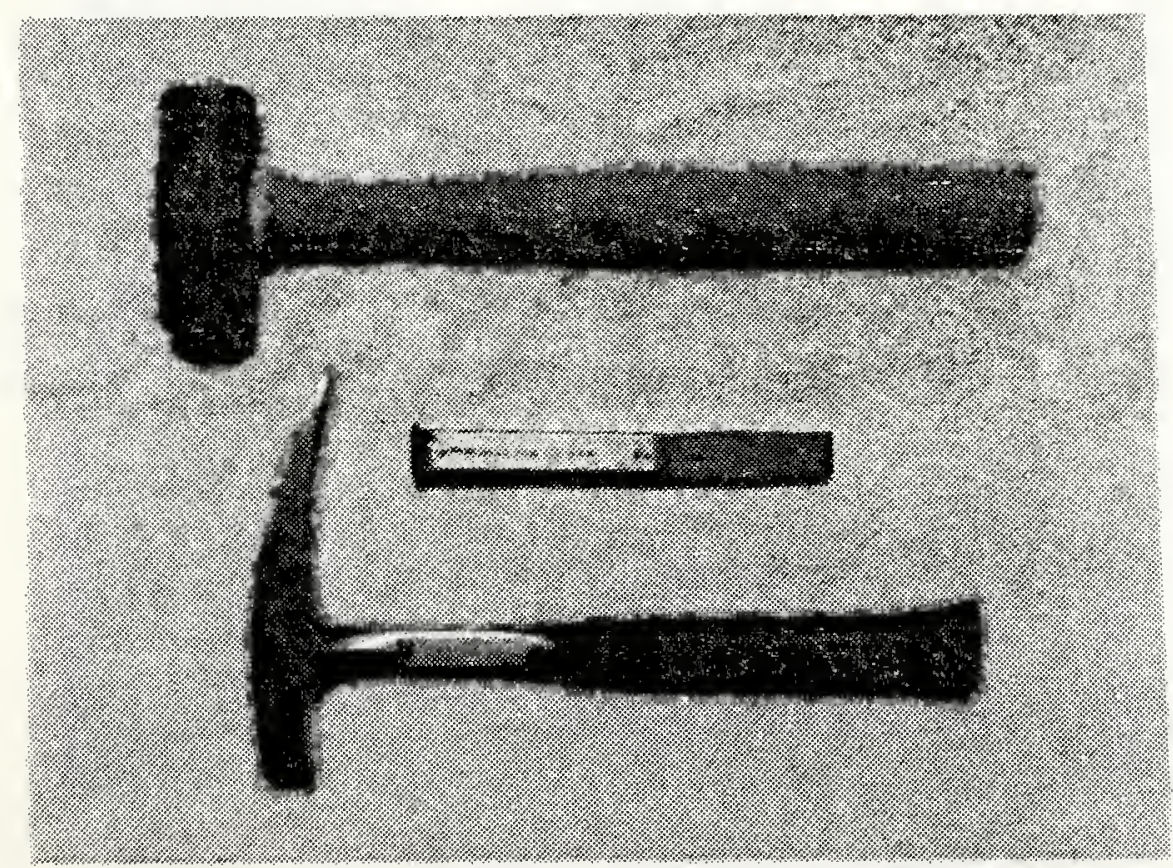

Figure 27. Equipment used to search for rock borers. 



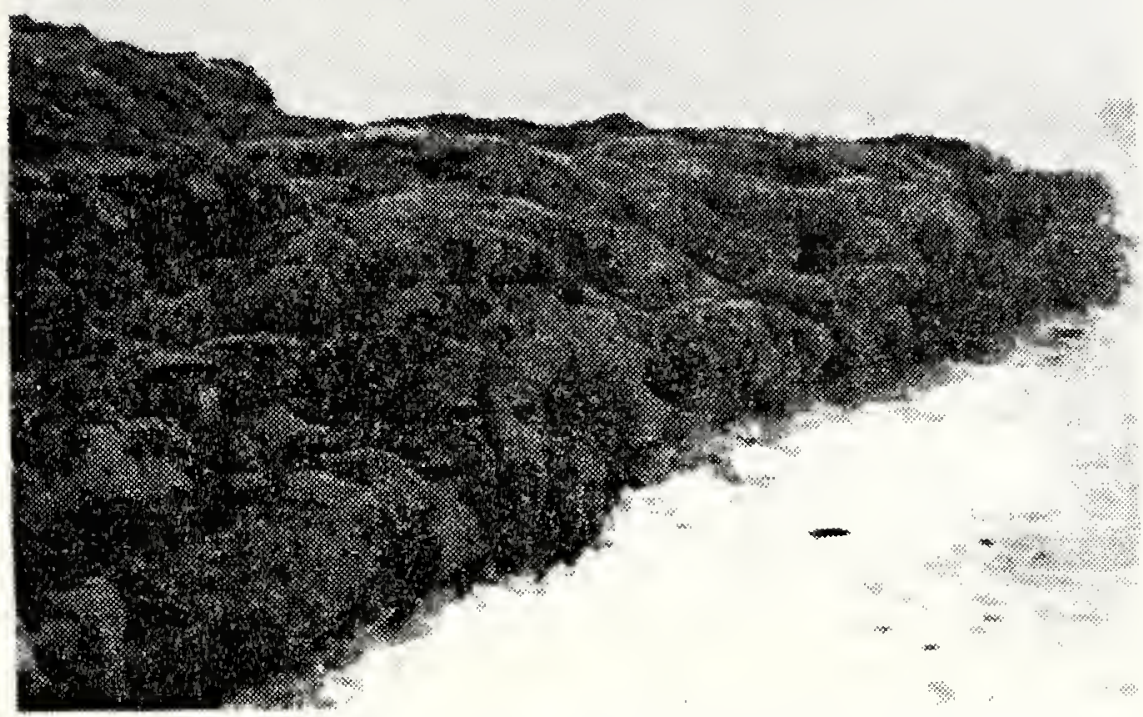

Figure 28. View of massive Phragmatopoma californica
colonies along western surge channel of Section $I$.

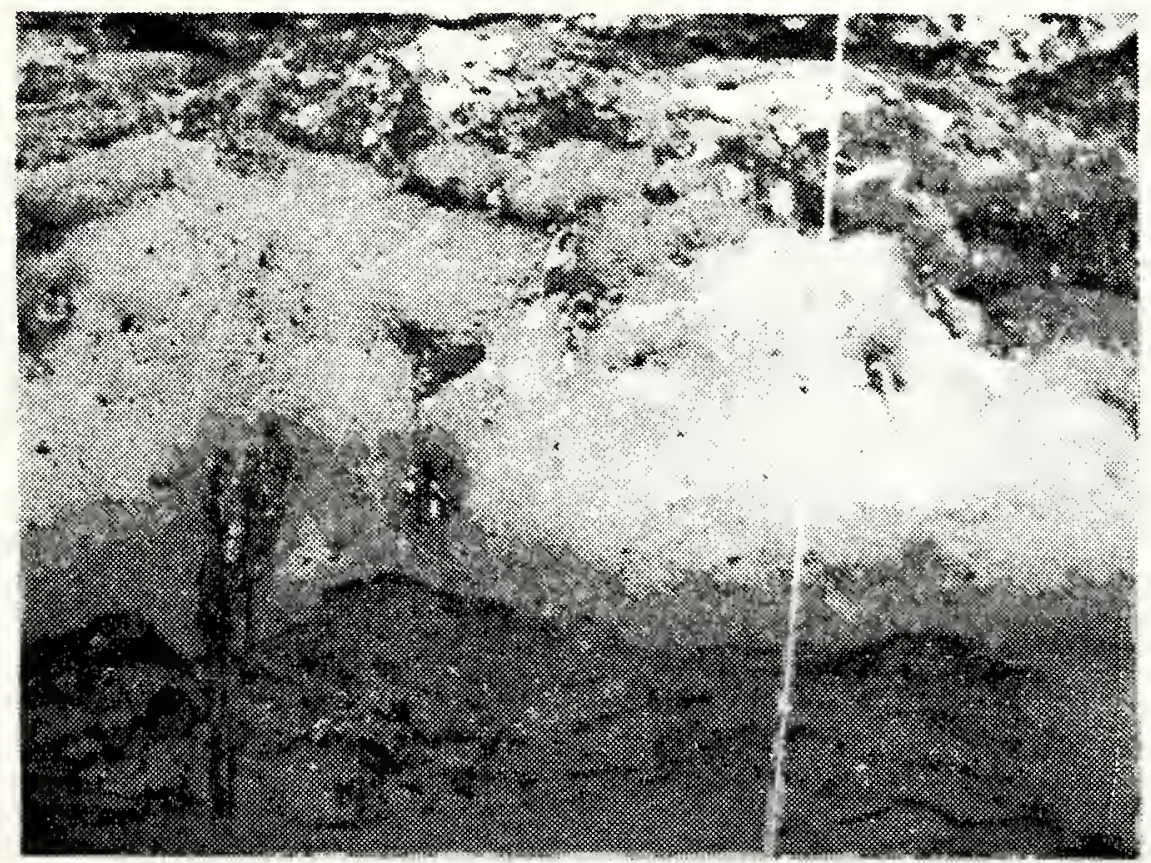

Figure 29. Close-up of Phragmatopoma californica colony showing Pollicipes polymerus protruding through colony. 



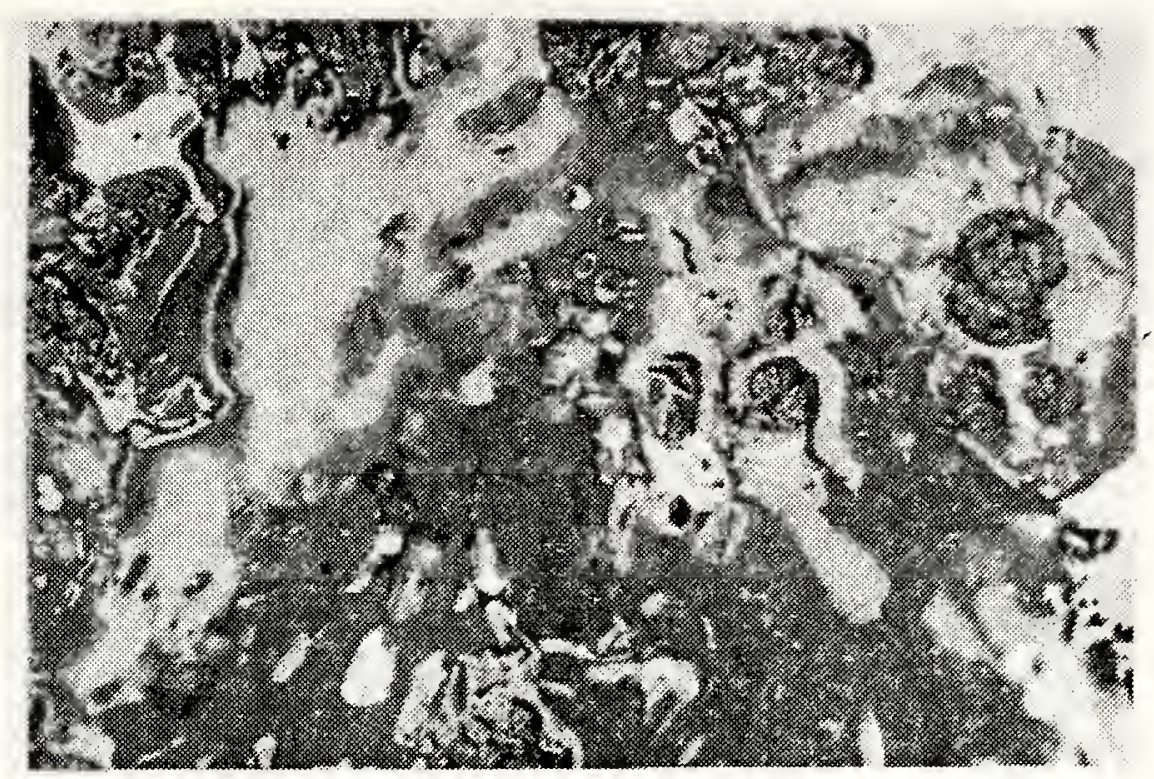

Figure 30. Photo showing dense cluster of Penitella penita
(more than 10 individuals are visible). Cluster is of $5 \times 15 \mathrm{~cm}$ area in section II of primary reef area with $1 \mathrm{~cm}$ of surface rock removed.

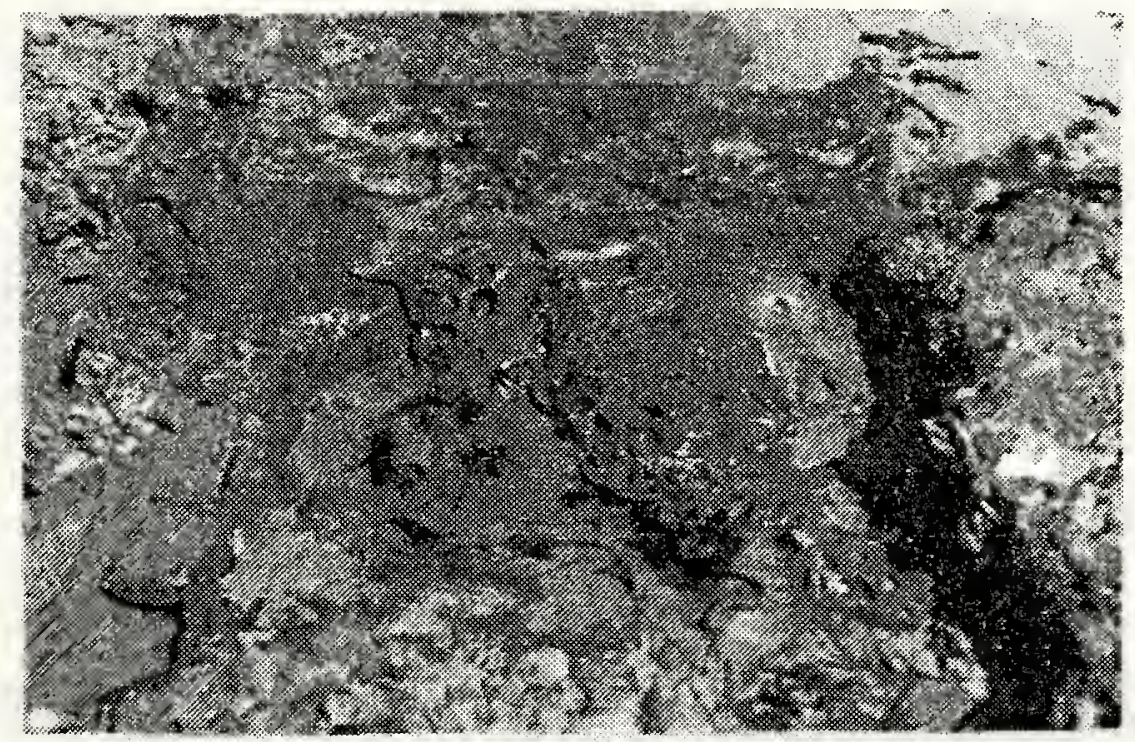

Figure 31. Photo from area of severe erosion showing evidence of pholad burrowing. 



\section{LITERATURE CITED}

Abbott, I. A. and G. J. Hollenberg. 1976. Marine algae of California. Stanford Univ. Press, Stanford, California, $827 \mathrm{pp}$.

Addicott, $W$. O. 1966. Late Pleistocene marine paleoecology and zoogeography in central California. U. S. Geol. Surv. Prof. Pap. 523-c:1-21.

Booth, S. B. 1971. The ecology and distribution of rockboring pelecypods off Del Monte Beach, Monterey, California, Master's Thesis, Naval Postgraduate School, Monterey, California.

Bramlette, M. N. 1946. The Monterey Formation of California and the origin of its siliceous rock. U. S. Geol. Surv. Prof. Pap. 212:1-57.

Burnett, N. A. 1972. The ecology of the benthic community of bivalve molluscs in the shale of the Monterey sewer outfall. Master's Thesis, San Francisco State University, San Francisco, California.

Clark, J. C. 1966. Tertiary stratigraphy of the FeltonSanta Cruz area, Santa Cruz mountains, California.

Ph.D. Thesis, Stanford University, Stanford, California.

Evans, J. W. 1968a. The effect of rock hardness and other factors on the shape of the burrow of the rock boring clam Penitella penita. Palaeogeog. Palaeclimitol. Palaecol. $4: 271-278$.

- 1968b. Factors modifying the morphology of the rockboring clam Penitella penita (Conrad, 1837). Proc. Malacol. Soc. London, 38:111-119.

- 1968c. The role of Penitella penita (Conrad, 1837) (family Pholadidae) as e roders along the Pacific coast of North America. Ecology 49:156-159.

Greene, H. G. 1977. Geology of the Monterey Bay region. Dept. of Int. Geol. Surv. Open File Report 77-718.

Haderlie, E. C. 1976. Destructive marine wood and stone borers in Monterey Bay. Proc. Third International Biodegradation Symposium: 947-953.

Haderlie, E. C., J. C. Mellow, C. S. Minter, III, and G. C. Booth. 1974. The sublittoral benthic fauna and flora off Del Monte Beach, Monterey, California. Veliger 17: $185-204$. 

Minter, C. S., III. 1971. Sublittoral ecology of the kelp beds off Del Monte Beach, Monterey, California. Master's Thesis, Naval Postgraduate School, Monterey, California.

Reid, C. 1907. Memorandum on the geological conditions affecting the coast of Holderness, Lincolnshire, and Norfolk, the south coast generally and the coast of Cornwall and North Devon. (Great Britain) Royal Commission on Coast Erosion, Report 1:165-172.

Smith, R. I. and J. T. Carlton (eds). 1975. Light's manual: Intertidal invertebrates of the central California coast. 3rd edition, Univ. Calif. Press, Los Angeles, California, 716 pP.

Turner, R. D. 1955. The family Pholadidae in the western Atlantic and eastern Pacific, Part II - Martesiinae, Jouannetinnae, Xylophaginae. Johnsonia 3:65-160.

Warme, J. E., T. B. Scanland, and N. F. Marshall. 1971. Submarine canyon erosion: contribution of marine rock burrowers. Science 173:1127-1129. 

1. Department of Oceanography, Code 68

Naval Postgraduate School

Monterey, California 93940

2. Oceanographer of the Navy, Code N-45

Hoffman II

200 Stovall Street

Alexandria, Virginia 22332

3. Office of Naval Research, Code 410

NORDA

NSTL Station, Mississippi 39529

4. Dr. Robert E. Stevenson

Scientific Liaison Office, ONR

Scripps Institution of Oceanography

La Jolla, California 92037

5. Library, Code 3330

Naval Oceanographic Office

Washington, D. C. 20373

6. SIO Library

University of California, San Diego

P. O. Box 2367

La Jolla, California 92037

7. Department of Oceanography Library

University of Washington

Seattle, Washington 98105

8. Department of Oceanography Library

Oregon State University

Corvallis, Oregon 97331

9. Commanding Officer

Fleet Numerical Weather Central

Monterey, California 93940

10. Commanding Officer

Naval Environmental Prediction Research Facility

Monterey, California 93940

11. Department of the Navy

Commander Oceanographic System Pacific

Box 1390

Pearl Harbor, Hawaii 96860 

12. Defense Documentation Center

Cameron Station

Alexandria, Virginia 22314

13. Library, Code 0142

Naval Postgraduate School

2

Monterey, California 93940

14. Director

Naval Oceanography and Meteorology

1

NSTL Station, Mississippi 39529

15. NORDA

1

NSTL Station, Mississippi 39529

16. Lieutenant Gerald Clark, U.S.N.

Inshore Undersea Warfare Group 2 USNAB Little Creek

Norfolk, Virginia 23521 



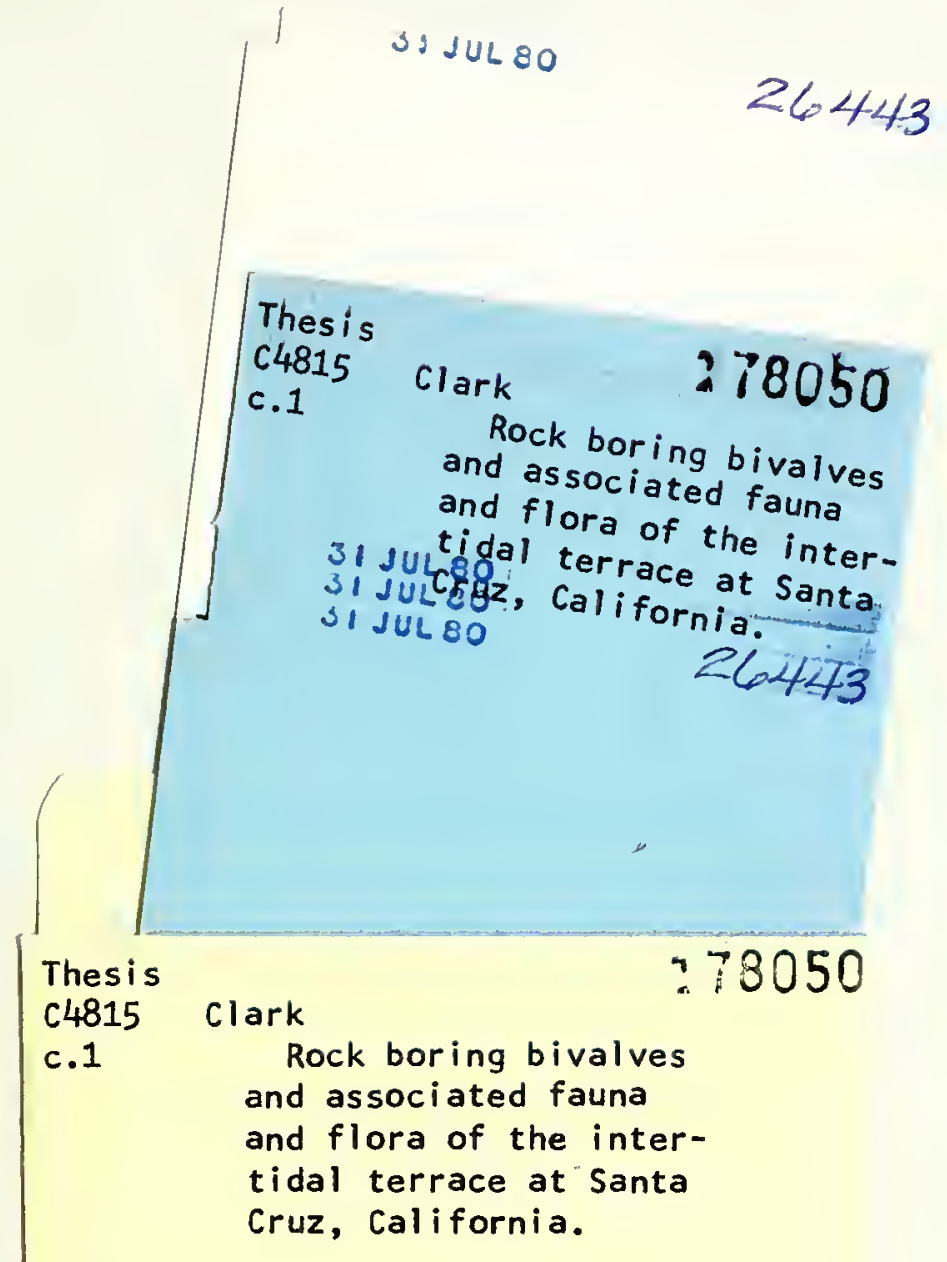


